MPC MAJOR RESEARCH PAPER

\title{
BETWEEN RHETORIC AND PROPAGANDA: \\ A CASE STUDY OF APPEALS TO PATHOS IN IRAQ WAR JUSTIFICATION \\ SPEECHES
}

\author{
BRYN TURNBULL \\ Professor Gregory Levey \\ The Major Research Paper is submitted \\ in partial fulfillment of the requirements for the degree of \\ Master of Professional Communication \\ Ryerson University \\ Toronto, Ontario, Canada
}

August 27, 2012 


\section{Author's Declaration for Electronic Submission of a Major Research Paper}

I hereby declare that I am the sole author of this Major Research Paper and the accompanying Research Poster. This is a true copy of the MRP and the research poster, including any required final revisions, as accepted by my examiners.

I authorize Ryerson University to lend this major research paper and/or poster to other institutions and individuals for the purpose of scholarly research.

I further authorize Ryerson University to reproduce this MRP and/or poster by photocopying or by other means, in total or in part, at the request of other institutions or individuals for the purpose of scholarly research.

I understand that my MRP and/or my MRP research poster may be made electronically available to the public. 


\begin{abstract}
This MRP explores the ethical dilemma inherent in the use of emotional appeals in political speeches. Taking a historical approach to the question of how ethics and emotion have played out in rhetorical theory and propaganda studies, I examine how political speakers use rhetorical appeals to pathos in order to gain support for controversial policies. I question where the "line" between legitimate rhetorical appeals to pathos and illegitimate, emotionally manipulative propaganda lies, and ask: do appeals to emotion constitute propaganda? What is the difference between a legitimate appeal to emotion and propaganda? What constitutes a "legitimate" appeal to emotion in political speech?

To answer this, I analyze three speeches made by Western political leaders justifying America's decision to invade Iraq in 2003. My analysis distinguishes different kinds of appeals to pathos, or emotion, within my data set and weighs each speaker's use of "legitimate" appeals to pathos against emotional appeals that are classified as "propaganda," according to Elspeth Tilley's Propaganda Index (2005).

My findings show that a large percentage of appeals to pathos in each speech analyzed meet the requirements for propaganda as defined by Tilley. Eighty-one percent of appeals to pathos in George W. Bush's “Message to Saddam” constitute propaganda; sixtyeight percent of appeals to pathos in Tony Blair's Speech to the British House of Commons constitute propaganda; and seventy-three percent of appeals to pathos in Stephen Harper's Speech to the Canadian House of Commons are considered propaganda as defined by Tilley. My findings showcase the ambiguity of "ethical" communication in political contexts, and underline the importance of critical audience engagement in political processes.
\end{abstract}




\section{Acknowledgments}

Many thanks to Greg Levey and Susan Cody, my supervisor and second reader, for their guidance and support throughout the writing process. Further thanks to Ryerson University, McGill University and my family for helping me reach this point in my academic career. 


\section{Table of Contents}

Author's Declaration for Electronic Submission of a Major Research Paper __ ii

Abstract _ _ iii

Acknowledgments __ iv

Table of Contents __ v v

List of Figures __ vi

List of Appendices__ vii

INTRODUCTION__ 2

KEY DEFINITIONS 6

LITERARY AND THEORETICAL REVIEW _ 8

Rhetorical Theory 8

Rhetoric as a Tool for Persuasion

Emotional Appeals (Pathos) in Rhetoric __ 9

Objectivity and Misuse of Rhetoric __ II

A Need for Ethical Standards___ 12

Political Rhetoric 14

Rhetoric as a Political Tool 14

Emotional Appeals in Politics 15

Political Truth and Ideology _ 16

Propaganda Theory _ 17

Defining Propaganda 18

Bernays and Propaganda 18

Van Dijk and Manipulation 20

Tilley and the Propaganda Index _ 22

CASE STUDY: FRAMING THE RHETORIC OF THE IRAQ WAR 25

Justifying Military Action_ 26

Framing The Rhetoric of War

METHODS 30

Aims 30

Research Questions: _ 30

Pathos Code _ 3 I

Propaganda Index _ 34

ANALYSIS _ 37

CONCLUSION

Appendix A 45

Appendix "B" 48

Appendix "C" 54

Appendix "D" 65

REFERENCES__ 7 


\section{List of Figures}

\begin{tabular}{|l|l|l|}
\hline Fig I & Broad Categories of Appeals to Pathos Identified in Theory & p.33 \\
\hline Fig 2 & Pathos Code & p.33 \\
\hline Fig 3 & Elspeth Tilley's Propaganda Index & p.35 \\
\hline Fig 4 & Propaganda Index Modification & p.35 \\
\hline
\end{tabular}




\section{List of Appendices}

\section{Appendix A \\ p.45}

Table I: Pathos Code - Appeals to Pathos Analytic Categories and Descriptions p.45

Table 2: Propaganda Index

p.46

Table 2(a): Propaganda Index Modification

p.46

Table 3: Rhetorical Similarities in Bush, Blair and Harper Speeches

\section{Appendix B}

\section{p.48}

Article I: Analysis - George W Bush's "Message to Saddam"

Article 2: George W Bush's “Message to Saddam Analyzed by Argument

Article 3: Analysis - Tony Blair's "Speech to the House of Commons"

Article 4: Tony Blair's "Speech to the House of Commons" Analyzed by

Argument

\section{Appendix D}

\section{p.65}

Article 5: Analysis - Stephen Harper's Speech to the House of Commons"

p.65

Article 6: Stephen Harper's "Speech to the House of Commons" Analyzed by 


\section{INTRODUCTION}

"States like these, and their terrorist allies, constitute an axis of evil, arming to threaten the peace of the world. By seeking weapons of mass destruction, these regimes pose a grave and growing danger ... The price of indifference would be catastrophic."

- George W Bush, State of the Union Address, I/29/2002

This MRP explores the ethical dilemma inherent in the use of emotional appeals in political speeches. Taking a historical approach to the question of how ethics and emotion have played out in rhetorical theory and propaganda studies, I question where the "line" between legitimate rhetorical appeals to pathos and illegitimate, emotionally manipulative propaganda lies.

To answer this, I analyze three speeches made by Western political leaders justifying America's decision to invade Iraq in 2003, for the purpose of finding Weapons of Mass Destruction concealed by Saddam Hussein. As an international conflict that was justified on the basis of finding weapons that were ultimately proven not to exist (Hinnebusch, 2007), the Iraq War, and specifically arguments made in favour of commencing operations in the Middle East, arguably used emotional appeals to strengthen claims for the need to intervene. As a case study, these speeches, given by George W. Bush, Tony Blair, and Stephen Harper, enable me to explore how, if at all, speakers use emotional appeals as a replacement for, rather than a complement to, legitimate, evidence-based arguments.

My analysis distinguishes different kinds of appeals to pathos, or emotion, ' within my data set and weighs each speaker's use of "legitimate" appeals to pathos against

\footnotetext{
${ }^{1}$ Please note that the terms "appeals to pathos" and "emotional appeals" are used interchangeably throughout the course of this paper.
} 
emotional appeals that are classified as "propaganda" according to Elspeth Tilley's Propaganda Index (2005).

To fully understand the nuances of political oratory in this context, I look at how theorists including Aristotle, Pat Gherke, and James Herrick explore the question of ethics in rhetoric; examine questions of responsibility and pathos in political discourse by drawing on concepts from theorists such as Kenneth Burke and Ted Brader; and outline_identifying features of propaganda as defined by Edward Bernays, Teun Van Dijk, and Elspeth Tilley.

$$
* * * * *
$$

In times of international uncertainty and domestic unrest, democratic populations look to political leaders to guide them. These leaders, backed by their respective governments and constituents, are relied upon to provide domestic audiences with accurate information, reliable arguments, and decisive plans of action to steer their country to stability.

The facts of a crisis, however, are rarely simple; and in order to guide, political leaders face the hard task of presenting relevant information to audiences in ways that maintain public trust in the political administration of the day. A political leader's role, then, lies less in informing the public of a crisis and solution than in convincing audiences that the government's intended course of action is the right one.

For this reason, rhetoric is an essential component of political speechmaking. Rhetoric, the art of persuasion, has been linked to political oratory since the classical era; as one of the philosophical fields defined by Plato and Aristotle, rhetoric aims to win over audiences or discursive opponents through well rounded argumentation. Rhetorical discourse comprises three key components: logos, an argument that draws 
upon the audience's critical reasoning faculties; pathos, an appeal to the audience's emotions; and ethos, an assurance of the speaker's own credibility (Aristotle, Rhetoric, I.I.1355).

The second of these three rhetorical fields is of particular concern for this analysis. Rhetorical appeals to pathos are frequently used tools in the political arsenal; they allow speakers to make the leap from logic to passion, and can inspire the audience to pride, sadness, determination or fear at will - a tactic that helps make audiences more receptive to a speaker's logical argument, and, in turn, to the message or action call in question.

But what happens when a speaker manipulates audiences' emotions in lieu of providing them with facts? While emotional appeals are indeed an important component of rhetorical discourse as a whole, appealing to an audience's emotions without properly conveying the logical or necessary facts of an issue can be misleading and in politics, using tactics such as fear-mongering in order to gain political support can be hugely detrimental to public policy. From a politician's point of view, however, resorting to such strategies in combination with providing a partial or distorted picture of the "facts" of a situation at hand may be seen as a necessary means of gaining support needed to pass controversial legislation.

Strategies such as these tend to appear in a more unscrupulous field than political rhetoric: propaganda (Black, 200I). As a means of effecting specific emotional responses in an audience in order to provoke predetermined action, propaganda relies upon appealing to an audience's emotions in a way similar to rhetoric; however, propaganda, with its negative implications, is seen as a more unethical form of emotional manipulation for political or material gain (Tilley, p.70). 
Using Iraq War justification speeches as my case study, I explore the line between propaganda and pathos, relying upon Elspeth Tilley's Propaganda Index to identify and determine how illegitimate appeals to pathos are used in political oratory. 


\section{KEY DEFINITIONS}

Appeals to Pathos/Emotional Appeals: I have chosen to use Aristotle's classic definition of pathos as a rhetorical device used to "excite" the "emotions" of the audience for the purposes of persuasion (Rhetoric, I.I.I355). An "appeal to pathos", also known as an "emotional appeal," is any argument that uses emotion as a primary means of persuasion.

Propaganda: In "Responding to Terrorism Using Ethical Means: The Propaganda Index” (2005), Elspeth Tilley defines “propaganda” as "an argument containing ... claim and warrant, but lacking relevant supportive data" (p.70). A point of note in this definition is that propaganda includes a lack or deliberate omission of information in a persuasive argument.

Illegitimate Propaganda: I will be using Teun Van Dijk's definition of “illegitimate propaganda" as set out in his 2006 work, "Discourse and Manipulation”. Illegitimate persuasion constitutes "forms of interaction ... that are in the interests of one party, against the best interests of the recipients" (p.360). A major identifying element of illegitimate persuasion is the presence of biased information, intended to cast the dominant or speaking party in a favourable light.

Political Communication: In “The Ethics of Political Communication” (I995), Manuel Pares i Maicas defines "political communication" as "not the same as political information ... It takes into account propaganda, disinformation, advertising, public relations as well as other forms of communication" for political purposes (49I). A major caveat that I took into consideration through my study is pointed out by Maicas: namely, that "because of its very nature, political communication is primarily persuasive. 
Thus ... its practice may include a more or less unabashed degree of propaganda or disinformation" (p.479). While this naturally complicates any discussion of ethics in political communication as a whole, the ultimate goal of my analysis is to uncover areas of political communication where a speaker chooses to rely on emotionally manipulative language for the purpose of gaining trust, rather than to communicate ideology. In his work, Maicas discusses the use of propaganda to communicate political ideology within or between party organizations - a context in which bias and propaganda are likely components of political speech. In my case study, I examine points where emotionally manipulative propaganda is used for the purpose of political and diplomatic gain - and where, it could be argued, emotional appeals are used in place of concrete evidence. For that reason, while I recognize that ideological bias will be a component of the speeches in my data set, I remain focused on political communication that uses emotional appeals as a potential replacement for, not as a complement to, a full argument.

$$
* * * * *
$$

From here, I discuss the three theoretical streams that have guided the development of my case study and analysis of ethics and emotional persuasion in political speech. 


\title{
LITERARY AND THEORETICAL REVIEW
}

This section explores the three theoretical streams which inform the topic of appeals to pathos in political speech: rhetorical theory, political rhetoric and propaganda theory. In each section, I explore the various approaches to pathos in rhetorical, political and propaganda theory and discuss how the question of ethics in communication has played out in each theoretical stream.

\section{Rhetorical Theory}

\section{Rhetoric as a Tool for Persuasion}

In its most general form, rhetoric is defined as the art of persuasive discourse.

As a classical field of study, rhetoric takes its roots from Aristotle, who gives the term its longstanding formal definition:

\begin{abstract}
Rhetoric may be defined as the faculty of observing in any given case the available means of persuasion. This is not a function of any other art. Every other art can instruct or persuade about its own particular subject-matter ... But rhetoric we look upon as the power of observing the means of persuasion on almost any subject presented to us (Aristotle, Rhetoric, I.I.I 355b).
\end{abstract}

As such, the subject of a rhetorical argument is moot: rhetoric can be used to persuade an audience or opponent in any given field of study or discourse.

Aristotle outlines three ways by which an orator may persuade his or her audience: first, by appealing to the audience through the use of logic, or logos; second, through convincing the audience of his or her moral character, known as ethos; and finally, by appealing to the audience's emotions through pathos: the strategy by which, as Aristotle puts it, a speaker comes to "understand the emotions - that is, to name them and describe them, to know their causes and the ways in which they are excited" (Rhetoric, I.I.1355). By effectively combining the three strands of rhetoric in a speech or 
debate, a speaker will persuade his audience or opponent by arguing a point that is (I) logically valid; (2) ethically just; and (3) emotionally meaningful.

The concept of persuasion itself is well set forth by Kenneth Burke (1969) who, in A Rhetoric of Motives, states that "persuasion ranges from the bluntest quest of advantage, as in sales promotion or propaganda, through courtship, social etiquette, education and the sermon, to a 'pure' form that delights in the process of appeal for itself alone, without ulterior purpose" (p.xiv). Burke points to "identification" as a primary means of effecting persuasion: a strategy whereby a speaker attempts to gain his or her audience's trust by aligning points of his or her speech with the audience's interests or desires. Burke specifically notes the case of the politician who, when addressing an audience of farmers, says 'I was a farm-boy myself' (p.xiv). Such a discursive act assures the audience that the speaker implicitly understands their concerns and lifestyle, thereby making him a more credible speaker. This tactic aligns itself well with Aristotle's pathos: Both rely on understanding and catering to listeners' emotions in order to gain the allegiance of an audience.

\section{Emotional Appeals (Pathos) in Rhetoric}

While any fully realized rhetorical argument will draw on all three strands of rhetoric to persuade an audience, appeals to pathos tease out the intangible and often illogical points of an argument: the points that can pull on heartstrings, rouse anger, create solidarity, or spark compassion - points that, in many cases, are the deciding factor between a rhetorical victory or defeat. In Rhetoric, Aristotle discusses how appeals to pathos serve to "change men so as to affect their judgment" (II.I.I378a). By changing the focus of a rhetorical argument from logic to emotion, a skilled orator will 
affect how his or her audience perceives the issue at hand, enabling him or her to gain an advantage over his or her discursive opponent.

In ideal rhetorical discourse, appeals to emotion are used to complement and enhance the logical and moral aspects of a given argument; however, as Pat Gehrke (2009) points out, this rhetorical balance is not always struck:

Glenn W Merry voiced a belief in the zero-sum relationship between reason and emotion and stressed the moral priority of reason when he wrote that 'the spoken word may light the fires of passion and unreason or it may inspire to highest action and noblest sacrifice as a nation of freemen' (p.30).

In circumstances where rhetorical discourse prioritizes emotional appeals over reason, the resulting argument can lead an audience, intentionally or inadvertently, to conclusions made on the basis of heated emotion, rather than on balanced intellect.

In the political realm, such "heated" appeals can draw upon a wide range of emotions in the course of a speech or debate; however, as Ted Brader (2005) notes, fear appeals are a particularly effective method of persuasion in political speech. Fear appeals subvert audience expectations by prompting audience members to second-guess pre-established beliefs; as Aristotle notes, an orator using fear appeals "point[s] out that [a danger] has happened to others who were stronger than they are, and is happening, or has happened, to people like themselves, at the hands of unexpected people, in an unexpected form, and at an unexpected time” (Rhetoric, II.5.1382-5). Ted Brader, author of "Striking a Responsive Chord" (2005), provides a deeper look into how fear appeals influence audiences by upsetting pre-established thought patterns:

Fear breaks a person out of routines, directs attention to relevant portions of the environment, and activates thinking about alternative courses of action. The motivational impact of fear is less certain, as it can stimulate either constructive action to deal with a threat, withdrawal, or immobility, depending on the person and situation. Absent signs of threat, a person is calm and behaviour is governed by routines (Brader, p.390). 
The advantage, then, to using fear appeals as a particular form of pathos lies in their ability to 'break' audience members out of established modes of thinking, enabling the speaker to provide alternative solutions to pressing problems.

\section{Objectivity and Misuse of Rhetoric}

Having discussed rhetoric as a whole and appeals to pathos in particular, I will now discuss ways in which rhetoric can be ethically misused. At its core, rhetoric is a communicative tool to be used for the purposes of persuading opponents and gaining audience approval. In this sense, rhetoric itself is ethically objective: it can be used to support an argument regardless of whether the argument is ethical or not. Maggie Lam (2007) identifies this characteristic of rhetoric, stating that, while "persuasive strategies are fairly benign" on their own, "it is the purpose for which they are used that makes them unethical" (p.II). Aristotle also touches on this, pointing out that while a rhetorical argument may center on the merits of enslaving a neighbouring city, "the question of whether it is not unjust [to do so] often does not trouble [the speakers] at all" (1.3.1358b).

Because of its inherent objectivity, rhetoric, and the persuasive power it holds, can be used for good or base ends; but, as James Herrick (1992) asks, "who is to decide what is good and base?" (p. I33). A speaker who misleads his audience knowing that he is arguing an ethically objectionable point can still use rhetorical tactics to great effect, thereby convincing an audience to support a position which they might otherwise oppose. Speakers who use rhetorical strategies to conceal or distort truth are nothing new: Aristotle points out that those who use rhetoric "rightly" can vastly improve a given state of affairs, while those who use it "wrongly" can "inflict the greatest of 
injuries" upon an audience or people (I.I.1355b). In The Ethics and Politics of Speech, Pat Gehrke (2009) hits upon the core of this issue, asking: "What does it mean for communication and rhetoric if those skilled in its arts can put them to the purposes of extraordinary evil?" (p.I).

The most striking example of this is the way in which Adolf Hitler used the power of speech to gain support for the Nazi Party prior to and during World War II. As a skilled orator, Hitler was able to harness the persuasive power of rhetoric and use it to gain support for policies with unspeakably evil ends; indeed, Kenneth Burke (1939) considers it a duty of audiences to engage in an "anti-Hitler battle" of critical analysis to "find all available ways of making ... Hitlerite distortions [of language] apparent" (Rhetoric of Hitler's 'Battle', p.84). Of course, as many theorists such as Gehrke point out, Hitler's persuasive strategies were highly effective (p.53) - what's more, the "strategies for persuasion condemned in Hitler's oratory are simply extreme versions of those more mundane strategies generally to be found at the core of effective persuasion" (p.55). The question that naturally arises from the "Hitler Example" remains relevant today: what is the ethical line between an "extreme" and an "effective" use of persuasive techniques?

\section{A Need for Ethical Standards}

As a result of instances like these, many theorists think that rhetoric itself should be measured against an ethical standard. James Herrick (1992) believes that rhetoric requires a "virtue ethic" - that is, an ethical standard based on the goods, or virtues, that arise through the proper use of rhetoric. Such "goods" as identified by Herrick include the search for and advancement of truth; the spreading of ideas; and the testing 
of propositions and possibilities (p. I44). An ethical standard based on emphasizing rhetoric's virtues would set truth as the primary goal of rhetorical discourse and would regard "unethical" rhetorical arguments as those that mislead or obscure truth from audiences.

Like Herrick, Gehrke (2009) sees merit in creating an ethical standard to guide rhetorical discourse; however, unlike Herrick, he believes that an ethical standard must be developed for the sake of regulating the orator, rather than the art form. "The justification of a rhetorical education require[s] a unique bulwark," Gehrke writes, "a safety mechanism that would provide a check against the possibility that a well-trained orator of ill intentions or unsavory moral character might turn the tools of rhetoric to antisocial ends" (p.67). Consequently, Gehrke feels that any ethical standard of rhetoric ought to be externally enforced, intended to identify and obstruct those who would use rhetoric for unethical purposes.

Essentially, any discussion of ethical guidelines for the use of rhetoric must consider that the idea of morality, or ethics, is not a fixed concept in contemporary society. Establishing an ethical basis by which to measure or regulate rhetorical discourse would, as Herrick points out, "run directly into the problem of contemporary urban society's divergent moral perspectives” (p.135). This suggests that Gehrke's conclusions for creating ethical standards fall short: to create an effective ethical standard for rhetoric, and for those who use it, we must look to rhetoric itself, rather than rely on the subjective moral standards of diverse audiences and users.

$$
* * * * *
$$

This section explored questions of ethics and responsibility in regards to the use of rhetoric as an objective tool. In the following section, I will examine how political 
rhetoric, as a particular category of rhetorical communication, makes use of appeals to pathos in ethical and unethical contexts.

\section{Political Rhetoric}

\section{Rhetoric as a Political Tool}

As an inherently persuasive field, political communication relies heavily upon rhetoric to create effective, diverse, goal-oriented messaging for a variety of audiences (Maicas, p.482). Consequently, it provides audiences and critics with ample ground to explore the benefits and drawbacks that persuasive speech has to offer.

In a democratic society, the role of managing or inducing cooperation between divergent audiences falls to political actors. According to Edward Bernays, Kenneth Burke and Noam Chomsky, without a political system to communicate societal goals and problems to mass audiences, community members would be incapable of prioritizing certain problems over others. As a result, "big picture" public issues would remain unresolved (Chomsky, 1983). It is for this reason that understanding how to effectively communicate such issues to audiences is a necessary component of any functioning society (Bernays, 1928). Edward Bernays (1928) felt that using "the psychology of public opinion" was an essential means of bringing about change and progress in political and social landscapes:

[Bernays] argued that since 'public opinion is slow and reactionary,' those who use the 'psychology of public persuasion ... to bring about changes in public opinion are performing a great public service" (Olasky, 1984, p.3).

Bernays terms this societal cooperation the "engineering of consent" - the process by which society's decision-makers communicate political, social and institutional issues to audiences, providing them with a mental framework within which to consider and 
prioritize tasks that need to be accomplished for the benefit of society as a whole (p. 120$)^{2}$

Rhetoric is a necessary component of political communication because it provides political figures with the tools to gain public support and consent. As Kenneth Burke (1946) states, rhetoric serves as a "symbolic means of inducing cooperation in beings that by nature respond to symbols" (p.43); thus, it encourages cooperation between divergent audiences by providing them with a unifying structure within which to consider issues or topics relevant to society at large.

$$
* * * * *
$$

As we have seen, rhetoric serves to induce cooperation between divergent audiences in the political realm and is thus an important field of political communication. Here, I will examine how emotional appeals can be used in specifically political contexts and discuss how ideology factors into discursive political persuasion.

\section{Emotional Appeals in Politics}

As in other discursive genres, emotional appeals are heavily used in political discourse. Ted Brader (2005) discusses how emotional appeals trigger particular responses in the minds of political audiences. By drawing on the "images, sounds and words" that link public action to personal experience in the minds of audience members, political speakers can bring issues from the background of public life to the forefront of an audience member's frame of reference:

\footnotetext{
2 Other social theorists, including Noam Chomsky, have shared the principles behind Bernays's concept of "consent engineering". Without the engineering of consent, Noam Chomksy (1983) argues, no social or political action would gain support except through violence or martial enforcement (Interview, The Manufacturing of Consent). Consequently, the tools of rhetoric help political speakers gain the consent of mass audiences, which facilitates cooperation between divergent audiences in the accomplishment of social goals.
} 
Images, sounds or even words that tap personal experiences or deeply ingrained symbols of success, failure or danger, can help unleash the desired emotional response in an audience: foreclosure signs and pink slips target recession-affiliated workers; flags inspire patriots and veterans; the screams of sirens and echo of gunfire rattle a crime-wary public; a chant of "no justice, no peace' invokes the specter of racial discord and urban riots among whites or structural discrimination and police brutality among blacks. Politicians use these cues to strike the responsive chord (Brader, p.390-I).

While Brader offers examples of using sensory cues to "strike the responsive chord", he identifies the importance of verbal communication in "elicit[ing] emotional reactions" to political messages (392). By using emotional appeals to "link" audiences mentally to a public issue or debate, speakers can more effectively frame the way in which the audience perceives the debate as a whole.

\section{Political Truth and Ideology}

In discussing ethics and political communication, one has to bear in mind that the notion of "truth" in political contexts is flexible. Fundamentally, political speakers seek to persuade an audience to believe in or follow one path over another; therefore, speakers with different political goals may present divergent versions of truth to audiences throughout the course of a political debate (Lam, p. 16). Such a state of affairs, naturally, implies that each version of "truth" as expounded by various political entities comes about as a result of political ideology, for, as Teun Van Dijk (2006) points out, social-political communication "always involves ideologies, ideological attitudes and ideological discourse structures" (p.374).

Because ideology is central to political discourse, objective truth is rarely ever the goal of political speech. Manuel Pares i Maicas (1995) discusses this aspect of political rhetoric, arguing that the discursive space between objective truth and political ideology often leaves room for unethical tactics of persuasion: 
One should take into consideration that, because of its very nature, political communication is primarily persuasive. Thus, even if political communication is basically political information, in practice it may include also a more or less unabashed degree of propaganda or disinformation, or the message may be elaborated upon via the technique or language of public relations or advertising (Maicas, p.479).

Thus, any ethical standard of political rhetoric must take into consideration that the primary goal of political persuasion is to communicate political goals and ideology, not objective truth. This does not, however, exempt politicians from ethical standards. The point at which emotional appeals are used to distort or omit evidence, even within ideological constraints, are considered unethical; and whether a politician inadvertently misrepresents facts or knowingly misleads audiences for "the greater good," maintaining an awareness of the ethical implications of such discursive acts remains an important part of establishing credibility as a speaker.

\section{Propaganda Theory}

I have discussed how both rhetorical and political communication theorists have considered emotional appeals and ethics in discursive contexts. From here, I will explore how propaganda theorists have dealt with the question of using rhetorical tactics to explicitly manipulate emotion and therefore opinion. Unlike classical orators who use rhetorical tactics in spite of the possibility of ethical misuse, propagandists use rhetorical tactics specifically because they allow the user to manipulate his or her audience. This section looks at how three theorists - Edward Bernays (1928), Teun Van Dijk, (2006) and Elspeth Tilley (2005) - have dealt with the question of propaganda and ethics. 


\section{Defining Propaganda}

As a cultural and theoretical construct, the term "propaganda" is hugely loaded with social and political implications. While the original sense of the word was neutral, ${ }^{3}$ "propaganda" has come to have extremely negative connotations; it is often associated with negative communicative practices in corporate public relations firms, media organizations and governmental organizations (Sproule, 1994, p. 10). Approaching the term from an ethical standpoint, Jay Black in Semantics and Ethics of Propaganda (200 I) provides a useful definition for the purposes of this paper:

Students of ethics should be struck by certain commonalities among most (but certainly not all) of the ... definitions [of propaganda]: a presumption of manipulation and control, if not outright coercion, that dehumanizes the audiences or intended 'victims' of propaganda; a power imbalance - rhetorical, political, economic and so forth - between propagandists and propagandees [sic]; and a presumption that principles of science, rhetoric, semantics and enlightened or open-minded education serve as powerful antidotes to propaganda (Black, p.I2I).

Of particular note in Black's definition is the aspect of manipulation and control that propaganda encompasses. Unlike persuasive techniques that draw on ethos, pathos and logos to allow audiences to make informed decisions on a topic, propaganda overrides an audience's ability to make a rational decision, often drawing heavily upon emotional appeals to overshadow a rational argument.

\section{Bernays and Propaganda}

According to Edward Bernays (1928), propaganda is "simply the establishing of reciprocal understanding between an individual and a group” (Propaganda, p.161). Unlike theorists who deem propaganda to be a negative and manipulative form of social

\footnotetext{
3 Propaganda: “(I) [mass noun] information, especially of a biased or misleading nature, used to promote a political cause or point of view ... (2) A committee of cardinals of the Roman Catholic Church responsible for foreign missions, founded in 1622 by Pope Gregory XV. Origin "Italian, from modern Latin congregatio de propaganda fide 'congregation for propagation of the faith' dates from the early $20^{\text {th }}$ century." (Oxford English Dictionary, 'Propaganda').
} 
control, Bernays sees it as a necessary tool for peacefully expediting social and democratic processes: by combining Freudian perspectives on emotion with traditional PR and marketing strategies, propaganda becomes "a consistent, enduring effort to create or shape events to influence the relations of the public to an enterprise, idea or group" (p.52). Through "understanding the mechanisms and motives of the group mind," Bernays argues, users can "control and regiment the masses according to [their] will without [the masses] knowing about it" (p.7I).

Bernays sees emotional appeals as central to a successful propaganda campaign, calling them "the steam which makes the social machine work" (p.74). By subtly manipulating the fears and desires of the audience, a propagandist or speaker can sway audiences into unconsciously thinking or acting in certain predetermined ways; through the course of a speech, a political speaker may "[create] circumstances which set up trains of thought" for the audience, thereby "mold[ing] the minds of the voters in conformity with his own ideas" on the topic at hand (p.I19). Indeed, using emotional appeals in social and political campaigns is central to Bernaysian propaganda; for, as Bernays points out, "the public is not made up merely of Democrats and Republicans. People are largely uninterested in politics, and their interest in the issues of [a] campaign must be secured by coordinating [the issues] with their personal interests" rather than on the basis of politics or policy alone (p.I I7).

While his methods are considered controversial, even “Machiavellian”, by many theorists (Olasky, 1984, p.6), Bernays believes that using propaganda to spread ideas is a necessary means of effecting institutional communication. However, he recognizes that propaganda can be used for "antisocial" ends. The "responsible" leader, therefore, must "be constantly aware of the possibilities of subversion" - by which Bernays means the 
misuse of propaganda tactics - and ensure that he "applies his energies to mastering the operational know-how of consent engineering, and out-maneuvering his opponents in the public interest" (Bernays, The Engineering of Consent, I947, p.I I5). The ethical responsibility for using propaganda lies, therefore, with the user: like Aristotle, who believes that "if another man argues unfairly, we on our part [must] be able to confute him" (I.I. 1355), Bernays believes that responsibility for using propaganda lies with the speaker him- or herself, both in terms of using it to "push only those ideas he can respect", and for "outmaneuvering" those who seek to abuse propaganda's ability to control and manipulate emotion (The Engineering of Consent, 1947, p.I 16).

\section{Van Dijk and Manipulation}

While Bernays sees merit in using propaganda techniques for "social" purposes, Teun Van Dijk (2006) regards propaganda as an illegitimate form of audience manipulation. In Discourse and Manipulation, Van Dijk distinguishes between ethically "legitimate" and "illegitimate" persuasive tactics in political contexts, arguing that the ultimate goal of illegitimate discursive manipulation lies in furthering the political agenda of those in control of the message, violating the audience's best interests.

According to Van Dijk, manipulation is "a communicative and interactional [sic] practice, in which a manipulator exercises control over other people, usually against their will or against their best interests" (p.360). He points to propaganda as a particular form of emotionally manipulative discourse, stating that such discourse "focus[es] on those cognitive and social characteristics of the recipient to make them feel more vulnerable and less resistant to manipulation" (p.376). Thus, Van Dijk's concept of manipulation aligns with Bernaysian propaganda: both seek to break down an 
audience's cognitive barriers, using psychological manipulation and emotional appeals to make audiences more susceptible to manipulative messaging. Van Dijk identifies several key ways that manipulative messages "break down" those cognitive barriers: these methods include providing audiences with "incomplete ... knowledge"; appealing to "fundamental norms, values and ideologies"; focusing on "strong emotions, traumas, etc. that make people vulnerable"; and using social power constructs of "social positions, professions, [and] status" to "induce people into tending to accept the discourses [and] arguments of elite persons, groups or organizations" (p.375).

According to Van Dijk, a key factor that distinguishes legitimate persuasion from illegitimate manipulation is the presence of power abuse; that is, manipulators "make others believe or do things that are in the interests of the manipulator and against the best interests of the manipulated" (p.360). Manipulative messaging presents audiences with incomplete or distorted knowledge of a situation, which allows the manipulator to frame discourse according to his or her own purposes (p.360). Conversely, legitimate persuasive messaging allows audiences to "believe and act as they please, depending on whether or not they accept the arguments of the persuader" (p.36I). As such, manipulation involves hiding the manipulator's true agenda or intentions from the audience. Much like the Orwellian politician who misleads audiences in a "consciously dishonest way" (Orwell, 1946) Van Dijk's manipulator provides audiences with one picture of reality while actively pursuing another. 


\section{Tilley and the Propaganda Index}

While both Bernays and Van Dijk provide theoretical context to the question of propaganda and ethics, Elspeth Tilley offers both a comprehensive look at propaganda from a theoretical perspective and a tool for identifying illegitimate propaganda within political discourse. In Responding to Terrorism Using Ethical Means: The Propaganda Index (2005), Tilley creates the Propaganda Index, a tool that I use in my analysis to distinguish legitimate persuasion from propaganda.

Propaganda, in the colloquial sense of the word, is fairly easy to identify. The word conjures up images of heroic young men in military dress, posters of women tilling verdant fields, caricatured enemies committing unspeakable acts, all underlined with catchphrases championing the "party line". According to Elspeth Tilley (2005), this kind of "black" propaganda is easy to identify: it is morally objectionable, "deliberately deceptive" in all senses of the word. Tilley points to a second category of propaganda that is much less easy to spot - "gray" propaganda, which is "not obviously untruthful but much more subtly manipulative" (p.70). In Responding to Terrorism Using Ethical Means: The Propaganda Index, Tilley identifies categories of gray propaganda in contemporary political settings, and offers a rhetoric-based approach to detecting gray propaganda - a more subtle, but no less ethically objective, form of emotional manipulation.

Like Van Dijk, Tilley believes that one of the major identifiers of propaganda is an omission or misinterpretation of relevant information in a message:

Propaganda is understood [...] as a communication that uses a specific set of rhetorical devices and cognitive heuristics to make claims or assertions, and to generalize (often unstated) broader assumptions from those claims, without providing evidence (p.70). 
While recognizing that "even when provided, 'evidence' is always in some way 'slanted' because truth is infinitely multiple, contested and subjective," Tilley believes that communicators must abide by some ethical standard when conveying information; rather than relying on a "familiar grab-bag of propagandistic rhetorical devices," communicators must move towards using a "pluralist, evidence-based communication style that offers data, research, history [and] context" to persuade audiences (p.70).

Tilley believes that the onus lies on communication theory to provide guidelines to "communication practitioners to assess their methods and messages" based on “ethical ends and ethical means" (p.69). While a communicator may not mean to mislead, his or her messaging may possess the characteristics of gray propaganda; consequently, Tilley believes that any productive identifier of propaganda must look at "textual criteria" rather than communicator intent as its base (p.7I). To accomplish this, Tilley developed the "Propaganda Index", a table that assists communicators in identifying propagandistic elements in political messaging. ${ }^{4}$ In developing a text-based approach to identifying propaganda, Tilley has created a method that responds well to Herrick's call for finding an ethical basis to communication that operates outside of “independent moral maxims" of a society.

$$
* * * * *
$$

I have considered the question of ethics and emotional appeals from three different theoretical backgrounds. With rhetorical theory, I examined the classical definition of rhetoric as provided by Aristotle; looked at rhetoric, and specifically, pathos, as a persuasive tool; discussed the danger inherent in using rhetoric for "undesirable" ends; and looked at the possibility of establishing ethical standards by

\footnotetext{
${ }^{4}$ Tilley's Propaganda Index (2005) may be found in Appendix A, Table 2.
} 
which rhetoricians could operate. In discussing political rhetoric, I explored the ultimate end of upholding ideology, rather than objective truth, in political discourse and discussed rhetoric's role in enabling political discourse and the democratic process. In the section on propaganda theory, I outlined three approaches to the idea of propaganda: Bernays's contention that propaganda is a necessary means of communication to be used at the ethical discretion of the propagandist; Van Dijk's notion of propaganda as a form of unethical manipulation, intended to reinforce the views and agenda of those in power; and Tilley's distinction between "black" and "gray" propaganda, as well as her contention that any criteria for monitoring propagandistic content in political discourse must be text-based, rather than contingent upon the communicator's often-unknown intent.

Now I will begin discussing my analysis itself, providing a context to my case study as a whole before explaining the methods that I used to analyze emotional appeals in political speeches. 


\section{CASE STUDY: FRAMING THE RHETORIC OF THE IRAQ WAR}

The Iraq War has arguably been one of the defining political events of a generation. The conflict, which lasted from 20 March 2003 to I5 December 20II, led to the eventual capture and execution of Iraqi President Saddam Hussein, yet remains one of the most controversial military operations to date. Indeed, while some academics such as David Mellow (2006) believe that the American intervention in Iraq served to accomplish vital military and humanitarian goals (p.297), others, including Richard B Miller (2008), argue that the Iraq conflict will be remembered as a war "lack[ing] a just cause" (p.65). While issues surrounding the causes and consequences of the Iraq War can be deliberated endlessly, the contextual focus for my case study lies in examining the ways in which pro-war governments presented the invasion to domestic and international audiences.

The question that bears asking at this point is: why does the Iraq War constitute a relevant case study for ethics in political discourse? Many believe that the war itself was unethical and see fault in how pro-war governments presented the war to domestic audiences. Scott and Ambler (2007) call the invasion "unethical”, asserting that it violated terms of the UN Charter and that the public was "knowingly misled" on the topic of Iraq's alleged noncompliance with UN Security Council resolutions requiring the country to disarm (p.70). John Dumbrell (2004) believes that "despite the [Bush] administration's best efforts, it proved difficult, indeed impossible, to establish a clear link between [Saddam Hussein] and the terrorist attacks of I I September, 200 I” (p.34). Ryan and Switzer (2009) note that "few in the media seemed to notice that Hussein was complying with UN directives or that Bush kept raising the bar for peace" (p.5I), while 
Altheide and Grimes (2005) point out that reports by "the International Atomic Energy Agency, the Central Intelligence Agency (CIA), the Department of Energy, the Defense Intelligence, the State Department and the Air Force, as well as key White House Cabinet members and advisors," actively "denied or cast serious doubt on Iraq's possession of WMD” (p.627).

Given the critical backlash to how governments presented the war to domestic and international audiences, the question of ethics is an important one. In analyzing how pro-war administrations rhetorically "framed" the war for audiences, I hope to reveal how and where unethical appeals to pathos can lie in political speech. By using war justification speeches as my case study to analyze the dividing line between rhetoric and propaganda, I hope to demonstrate the extent to which ethically ambiguous rhetorical tactics can be used in modern political discourse.

\section{Justifying Military Action}

The Bush administration relied on several key claims to justify invading Iraq in March 2003. The most prominent justifications centered on allegations of Saddam Hussein's noncompliance with UN Security Council directives to disarm Iraq's nuclear weapons programmes, as well as its suspected participation in the $9 / 1 \mathrm{I}$ attacks on the World Trade Centre (Kumar, 2006, p.54). The Bush administration argued that Iraq, given its alleged links to Al Qaeda, posed a direct and immediate threat to the national security of the United States of America and other Western democracies: using weapons of mass destruction (WMDs) previously concealed from UN weapons inspectors, Iraq could "help" terrorists obtain "chemical, biological, or, one day, nuclear weapons" to "kill thousands or hundreds of thousands of innocent people in our 
country or any other" (Bush, Message to Saddam, 2003). The necessary course of action was to invade Iraq before it could build its weapons capabilities to the point where it could strike against the United States. Subsequent reports, as Altheide and Grimes (2005) point out, would show that these claims were false:

There was very little reporting by major news media about contrary views cautioning that this attack was not necessary at the time, that [UN] weapons inspectors had not found such weapons and needed more time to work, and that sanctions already in place were working (p.6I8).

Richard B. Miller agrees that the reasons provided to western audiences for the invasion were misleading, stating that "there is not, nor was there at the time, sufficient evidence to say that the United States was in danger from Iraq, to conclude that the UN resolutions authorize the use of force to depose Saddam, or to argue that existing mechanisms of legal enforcement were ineffective ... Nor is there sufficient evidence to say that his dictatorship was such that humanitarian intervention was justified in 2003" (p.65).

\section{Framing The Rhetoric of War}

The use of fear appeals in the context of the Iraq war is well documented. Using the emotionally laden rhetoric of $9 / \mathrm{I}$, and labeling Hussein and the Iraqi government as "terrorists" or terrorist sympathizers, the Bush administration was able to draw upon a "politic of fear" to instill a sense of fear and urgency in its audience (Altheide, 2006, p.416). Fear appeals used by the Bush and Blair administrations drew heavily on 9/II rhetoric to make broad and explicit claims of collusion between Iraq and AI Qaeda operatives. These claims, notes Richard Falk (2004), were adopted by the mainstream media and presented as fact:

[T] he national trauma induced by the Al Qaeda attacks generated a series of responses based on a national climate of fear and anger impressively orchestrated by the Bush leadership and a 
compliant mainstream media: the immediate uncritical adoption of a war mode of discourse as the basis of anti-terrorism (and the associated degeneration of prior reliance on a law enforcement mode) ... the mobilization of American patriotism; an insistence on defining the struggle as against 'terrorism' in general, including anti-state movements of self-determination; the enunciation of a vague and self-serving doctrine of pre-emptive war; and the insistence that all governments either join with the United States or be regarded as aligned with 'the enemy' (p.25).

These claims, and others like them, set the stage for war justification rhetoric in relation to Iraq as a whole. As Deepa Kumar (2006) points out, a major means of substantiating these claims was through "guilt by suggestion". By mentioning Iraq and Al Qaeda in the same sentence, accusers effectively "linked" the two parties in the minds of their audience:

The implication is that Iraq must support Al Qaeda. While Iraq may have had ties to organizations that the US considered to be 'terrorists,' and while there may have been Al Qaeda stationed in Iraq, juxtaposing the two sent sent the message that Iraq supported Al Qaeda and encouraged them to set up camp in Iraq (Kumar, p.55).

By drawing connections between the Iraqi government and Al Qaeda, political speakers effectively mobilized and politicized national opinion, “influence[ing] audiences' mental models" by "polariz[ing]" the war debate into "a case of Us (good, innocent) and Them (evil, guilty)" (Van Dijk, p.370).

A particularly effective way that speakers achieved this was through labeling the Iraqi government terrorists or terrorist sympathizers. Labeling, as Maggie Lam (2007) notes, "attempt[s] to impart value judgments and thus express[es] an ideology that is biased". It thus "empowers and marginalizes simultaneously", lending credibility to the speaker as a voice of reason against those labeled (Lam, p.4I). This enabled politicians and media outlets to "market and frame fear and dread of terrorism as part of a national 
identity... Terrorism became a very broad symbol that encompassed fear, consumption, and international intervention" (Altheide \& Grimes, p.620). ${ }^{5}$

I have discussed how rhetoric used by pro-war governments was used to mobilize audiences in support of war efforts. Through the use of fear appeals, Us/Them polarization and labeling, speakers gained popular support for a fundamentally polarizing military initiative. From here, I will be explaining the methods used to analyze emotional appeals in political speeches, using Elspeth Tilley's Propaganda Index to identify illegitimate emotional manipulation and propaganda in my case study speeches.

\footnotetext{
${ }^{5}$ The effectiveness with which the Bush administration linked the Iraqi government and Hussein to terrorism, "evil", and the 9/II attacks can be seen in surveys cited by John Dumbrell (2005): in March 2003, $88 \%$ of American respondents believed that Iraq supported terrorist organizations that threatened the US, and $5 \mathrm{I} \%$ felt that Saddam Hussein was personally implicated in the $9 / \mathrm{II}$ attacks (34). To further condemn Iraq, the United States "emphasized Iraq's alleged lack of compliance with international law," accusing the country of harbouring WMDs - on 26 August, 2002, Vice President Dick Cheney publicly stated that "there is no doubt that Saddam Hussein now has weapons of mass destruction. There is no doubt he is amassing them to use against our friends, against our allies, and against us" (as qtd in Scott \& Ambler, 2007, p.75).
} 


\section{METHODS}

To this point, I have discussed the context in which Iraq War justification speeches were given, providing a particular focus on the kind of rhetoric which pro-war speakers used to "frame" the war and have provided readers with an appropriate theoretical background from which to consider questions of rhetorical ethics and propaganda theory. In the following section, I will discuss how I conducted my analysis, outlining the methods used in my case study.

\section{Aims}

My research sought to identify what differentiates rhetorically legitimate appeals to pathos from propaganda as a negative, manipulative form of discourse. I used Iraq War justification speeches as my case study because many of the reasons given to audiences for invading Iraq drew upon points that truly hit the emotional core of international audiences: the September II attacks, global terrorism, and threats to the

democratic system of governance. The use of these highly emotional arguments in the speeches analyzed in my case study provided me with ample ground to explore the question of appeals to pathos in political speech and enabled me to discuss the topic in a critically engaging light.

\section{Research Questions:}

I.0 What is the difference between a legitimate appeal to emotion and propaganda?

2.0 What constitutes a "legitimate" appeal to emotion in political speech?

I used a threefold method to analyze appeals to pathos in my case study. First, I identified appeals to pathos using a "Pathos Code" developed for the purposes of this 
MRP. Second, I determined whether each appeal was ethical or not based on whether or not it is considered "propaganda" under Elspeth Tilley's Propaganda Index. Finally, I measured the frequency of "ethical" appeals to pathos as compared to "unethical" appeals to pathos in each speech, which resulted in a final determination of how much each speaker relied upon unethical appeals to pathos.

\section{Pathos Code}

I developed the Pathos Code in order to identify different kinds of appeals to emotional appeals within my data set. To create it, I studied various kinds of appeals to pathos outlined by different theorists. From there, I refined those appeals into different categories based on the context and subject matter of the speeches themselves. The final form of the Pathos Code consists of six categories into which relevant appeals to pathos may fall. ${ }^{6}$

While researching the theoretical background for my paper, I discovered three broad themes of emotional "tactics" that theorists point to as a means of persuading audiences. These tactics fell into three main categories that informed the development of the Pathos Code: fear appeals, key words and labels, and ideology (as shown in Fig. I, below).

Fear appeals are relevant components of rhetorical and propagandistic discourse because they allow speakers to upset audience members' feelings of complacency or security (Brader, p.390). Incorporating fear appeals into speeches allows speakers to reset fundamental audience expectations, a necessary rhetorical step, for, as Aristotle points out, "if fear is associated with the expectation that something destructive will

\footnotetext{
${ }^{6}$ Full details of the Pathos Code may be found in Appendix A, Table 1.
} 
happen to us, plainly nobody will be afraid who believes nothing will happen to him" (II.5. I 382). Consequently, a speaker must make the audience believe they are in danger - which, as Van Dijk notes, "makes [them] more vulnerable and less resistant to manipulation, more credulous and willing victims" of propaganda (p.376).

Focusing on a series of key words and labels enables a speaker to define the terms by which his or her speech will be received. As Maggie Lam (2007) states, "lexical terms carry with them a value judgment" - consequently, labeling makes audiences more receptive to the ideas that a speaker wants them to hear; or rather, these acts "[make] judgment for the hearers" (p. 16). In Politics and the English Language (1946), George Orwell points to the inherent emptiness that politically loaded terms often carry, stating that such terms "are almost completely lacking in meaning." He identifies fascism as an example of a word that "has now no meaning insofar as it signifies 'something not desirable"'; this particular term has arguably been replaced in modern political discourse with the equally laden terms "terrorist," "terrorism" and "terror" (Van Dijk, p.370). Using such phrases predisposes audiences to perceive the recipient of such a label in a negative light, regardless of what their true intentions may be.

As previously discussed in this paper, political discourse involves a measure of ideology that informs and directs its communicative strategy. Consequently, emotional appeals are often used to enhance ideological arguments. Van Dijk identifies the kinds of emotional appeals that are directed by ideology, stating that "such manipulative policies and discourses [involve] nationalist feelings, Us/Them polarization and a systematic negative representation of the Other in terms of negative values, characteristics and actions" (p.374). These appeals attempt to distance audiences from opposing political 
parties or ideas, and rationalize the speaker's point of view as, ostensibly, the most reasonable or logical solution under consideration.

Fig. I

Broad Categories of Appeals to Pathos Identified in Theory

\begin{tabular}{|l|l|}
\hline Emotional “Tactic” & Theorist \\
\hline Fear Appeals & Aristotle, Brader, Van Dijk \\
\hline Key Words/Labels & Lam, Orwell \\
\hline Ideology & Van Dijk, Maicas \\
\hline
\end{tabular}

Using the framework provided by the three major emotional "tactics" defined above, I identified six categories of emotional appeals within the speeches in my data set. Edward Bernays argues that emotional appeals must "coincide with the broad basic plans of the campaign" (p.I I6), so I refined the Pathos Code to address the specific subject matter of my data set as a whole. With that, I developed six categories into which appeals to pathos fall (Fig. 2):

Fig. 2

\section{Pathos Code}

\begin{tabular}{|l|l|}
\hline Category & Definition \\
\hline Threat to National and/or Global Welfare & $\begin{array}{l}\text { Emphasis upon nationalistic/patriotic sympathies; suggestion of imminent threat to } \\
\text { the nation or world at large. Includes references to "protect[ing] the "nation", } \\
\text { "world" / "national interests" or "global security" against "enemy invasions". Invokes } \\
\text { need to "defend" the homeland or western way of life. }\end{array}$ \\
\hline Fear and Urgency Appeals & $\begin{array}{l}\text { Emphasis upon the need for immediate or offensive action. Invokes sense of time } \\
\text { "ticking down" to impending "doom" or "terror". Speculation of dangers yet to } \\
\text { come and need to meet them immediately. }\end{array}$ \\
\hline Vilification of the "Other" & $\begin{array}{l}\text { Projection of negative or aggressive tendencies and biases upon the "enemy" or } \\
\text { "unsupportive" UN member states. Use of politically charged terms and labels to } \\
\text { refer to or imply that the "other" is the "enemy" or resistant to the "needs" of the } \\
\text { world. }\end{array}$ \\
\hline Historical Allusion & $\begin{array}{l}\text { References to: } \\
\text { (a) prior dictatorships, authoritarian regimes or international conflicts } \\
\text { (b) September II attacks on the Twin Towers }\end{array}$ \\
\hline Fate of Iraq & $\begin{array}{l}\text { Invocation of specific emotional response in audience that connects current situation } \\
\text { to past injustices }\end{array}$ \\
\hline $\begin{array}{l}\text { Condemnation of the injustices against Iraqi people; invoke feeling of outrage or } \\
\text { indignation in audience, encourage need to intervene and provide "noble" assistance }\end{array}$ \\
\hline
\end{tabular}

Further details pertaining to the Pathos code may be found in Appendix A, Table I. 


\section{Propaganda Index}

After coding appeals to pathos within my data set using the Pathos Code, I determined their ethical legitimacy based on whether or not they constituted “propaganda”, as defined by Elspeth Tilley’s Propaganda Index (Fig. 3). The Propaganda Index identifies illegitimate persuasive arguments within a text based on whether or not the argument contains propagandistic elements: it "identifies what particular rhetorical devices typically characterize propaganda" and provides a "reliable means of measuring [propaganda's] presence” in a given argument (Tilley, p.7I).

As an effective and useful means of identifying propaganda, Tilley's Propaganda Index is an appropriate device to distinguish legitimate persuasive techniques from propaganda as illegitimate persuasion. Theorists such as Ryan and Switzer (2009) have drawn upon the Propaganda Index to study propaganda in media settings. As Ryan and Switzer note, Tilley's work allows "ethical communicators" to avoid "serv[ing] someone's narrow agenda, mak[ing] claims that are not evidence-based, spread[ing] lies and deception, supply[ing] incomplete or misleading information" (p.49). In her own study, Tilley uses the Propaganda Index to identify propagandistic content in an Australian government terror information package. While my use of the Index is comparable on the basis of subject matter (terrorism), it does not overlap with her case study so much as to be redundant.

The Propaganda Index defines seven categories of propaganda-based arguments: Name Calling, Glittering Generality, Transfer Positive, Transfer Negative, Plain Folks, Band Wagon and Manifest Destiny (Fig. 3): 
Fig.3

\section{Elspeth Tilley's Propaganda Index}

\begin{tabular}{|c|c|}
\hline Device & Description \\
\hline Name Calling & $\begin{array}{l}\text { Negative or "bad" labels or stereotypes (e.g. terrorists, extremists, fanatics, ferals, "rent-a- } \\
\text { crowd") that encourage a summary negative response without examining history, complexity, or } \\
\text { evidence related to an issue }\end{array}$ \\
\hline Glittering Generality & $\begin{array}{l}\text { Abstract positive labeling using virtue connotators (e.g., intelligence for covert surveillance); } \\
\text { positive-sounding euphemisms (e.g., collateral damage and friendly fire for civilian or own-troop } \\
\text { deaths; biosolids for sewerage); broadly affirmative unverifiable adjectives (e.g., state-of-the-art, } \\
\text { high-tech); positive abstractions (e.g., prosperity, freedom, rights, democracy, respect, common } \\
\text { sense); vagaries (e.g., significantly increasing or highly trained, where the level of increase or } \\
\text { training is not defined); subjective adjectives or adverbs (beautiful, stunning) which give positive } \\
\text { effect without evidence }\end{array}$ \\
\hline Transfer Positive & $\begin{array}{l}\text { Process of association whereby the "good" of one thing rubs off onto something else (e.g., } \\
\text { through appropriation of symbolic objects such as national flags or anthem, sponsorship, celebrity } \\
\text { or "expert" endorsement) }\end{array}$ \\
\hline Transfer Negative & $\begin{array}{l}\text { Express or implied association with negative incidents, places, people or symbols to "rub off" } \\
\text { negative qualities to the issue being discussed or discredit by implication an opposing viewpoint } \\
\text { (e.g. may have links with Al Qaida [sic] has been seen in the company of known terrorists, etc.) }\end{array}$ \\
\hline Plain Folks & $\begin{array}{l}\text { Implication that ideas are "of the people" (e.g., references to family values, hard working decent } \\
\text { folk, normal people, or middle Australia). PF is a values-based device that implies normalcy [sic] } \\
\text { or rationality for an opinion and thereby demonizes other views as aberrant and unreasonable, } \\
\text { even if they are majority }\end{array}$ \\
\hline Band Wagon & $\begin{array}{l}\text { Peer pressure or spiral of silence device (e.g., implication that everyone, most people, many } \\
\text { people or any large collectivized group of people such as our school, our company, or our } \\
\text { neighbourhood thinks a particular, singular and uniform way). Includes references to imagined } \\
\text { communities such as states, nations, organizations, and phrases such as we, our, all, everybody } \\
\text { that invite solidarity with an implied large and inclusive group, suggest mass support for an } \\
\text { opinion, marginalize alternative views as minority, suggest collective ownership of and } \\
\text { responsibility for the actions of a group (e.g., "our army") or obscure internal division within a } \\
\text { group }\end{array}$ \\
\hline Manifest Destiny & $\begin{array}{l}\text { Deterministic invocation of God (of any kind or faith), destiny, fate, natural processes, or } \\
\text { universal design, to lend support to an argument; removal of accountability for an idea or issue } \\
\text { from individuals and attribution of responsibility to deterministic "greater forces" (God's will, } \\
\text { karma, tradition, luck, History, Nature) }\end{array}$ \\
\hline
\end{tabular}

As my analysis focuses solely on appeals to pathos, certain categories of the Propaganda

Index were more applicable than others. Therefore, I modified one category of the

Index to fit more comprehensively within the parameters of my study. In my analysis I

altered "Glittering Generality" (not broadly evidenced in the speeches) to "Grim

Generality”, which I define as the use of abstract negative labeling intended to give

negative effect without evidence. Figure 4 expands upon this category.

Fig 4:

Propaganda Index Modification

\begin{tabular}{|l|l|}
\hline Device & Description \\
\hline Grim Generality & $\begin{array}{l}\text { Abstract negative labeling using vice connotators; negative-sounding } \\
\text { euphemisms; broadly negative unverifiable adjectives (e.g., danger, chaos); } \\
\text { vague speculation of negative eventualities (e.g., "should our enemies strike"); } \\
\text { negative abstractions (e.g., evil, danger, immoral); subjective adjectives or } \\
\text { adverbs which give negative effect without evidence }\end{array}$ \\
\hline
\end{tabular}


After identifying appeals to pathos within each speech and determining their ethical legitimacy with the Propaganda Index, I compared the number of legitimate to illegitimate appeals to pathos within the entire document, making a final determination of how much of each speech, if any, has made use of unethical propaganda. 


\section{ANALYSIS}

My results show that a large percentage of appeals to pathos in each of the three speeches analyzed meet the requirements for propaganda as defined by Elspeth Tilley.

George W Bush's speech, “Message to Saddam," given on March 17, 2003, is a presidential address that formally declares America's intention to invade Iraq within 48 hours of airing. It provides reasons why it condemns Iraq for not disarming at the UN Security Council's wishes, and threatens military consequences, enforced by the United States and their allies in lieu of UN Security Council members who, according to Bush, have not "lived up to [the UN's] responsibilities" to oust the Iraqi dictator.

Rhetorically, the speech draws heavily on pathos to support its argument for why the United States must invade Iraq without the formal sanction of the United Nations. I identified 26 appeals to pathos in the speech, $81 \%$ of which constitute propaganda as defined by Tilley's Propaganda Index. The most common forms of propaganda found in the speech are Name Calling ( 9 counts) and Grim Generality (6 counts). ${ }^{8}$

Bush uses appeals to pathos in this speech to inform US citizens both of the inevitable need to invade Iraq ("We are now acting because the risks of inaction would be far greater") and to assure his audience that all military action is undertaken with the long-term interests of the Iraqi people in mind ("The tyrant will soon be gone. The day of your liberation is near"). While the latter assurance is literally spoken to Iraq's listening audience in a "translated radio broadcast", its inherent emotional appeal is directed at US audiences and serves to comfort domestic listeners that the campaign is

\footnotetext{
${ }^{7}$ Full text of my analysis of Bush's "Message to Saddam" may be found in Appendix B, Article 2.

${ }^{8}$ Full details may be found in Appendix B, Article I and 2.
} 
set against "the lawless men who govern Iraq", rather than against the Iraqi people themselves. This strategy rhetorically overlooks the impact that such a campaign would inevitably have on civilian life, leading audiences away from thinking about the human toll that military action requires in much the same way that the term "friendly fire" is used to euphemistically skim over deaths involved in its action.

Bush's speech enables him to provide a comprehensive character portrayal of Hussein as a dictatorial tyrant, thereby allowing him to "frame" the terms of the invasion to his domestic audience. Bush's use of Name Calling ( 9 counts) helps him establish a negative image of Hussein to his audience, thus polarizing the debate between one of Good (“We are a peaceful people - yet we're not a fragile people”) and Evil, as personified by Hussein and the Iraqi government ("The regime has a history of reckless aggression ... It has a deep hatred of America and our friends. And it has aided, trained and harboured terrorists"). By restricting his condemnation of Iraq to the government and Hussein himself, Bush allows himself room to follow a humanitarian theme in his argument, the implications of which I have already discussed.

Tony Blair's Speech to the House of Commons, given on March 18, 2003, draws upon similar emotional rhetoric used by Bush while providing a more detailed account of the events leading up to the invasion of Iraq. Like Bush, Blair seeks to convince his audience of the ideological and military necessity of ousting Saddam Hussein from Iraq. However, unlike Bush, Blair attempts to persuade his audience that his recommended plan of action - namely, allying with the United States in invading Iraq - is politically as well as morally necessary. This aspect of the speech underlies the difference between the kind of audience Blair is addressing and Bush's audience. While Bush's "Message” communicates a predetermined plan to the American people, Blair, like Harper, seeks to 
convince his political audience to take a necessary course of action - namely, allying with the United States. This need for support greatly influences Blair's use of appeals to pathos throughout this speech, for he seeks not only to condemn Hussein, but also to invalidate the alternatives offered by his political opponents.

In his speech to the House of Commons, Blair uses pathological appeals to (a) vilify Hussein and the Iraqi regime; and (b) point out the multiple diplomatic and military dangers inherent in not enforcing UN sanctions against Hussein. ${ }^{9}$ Twelve of Blair's 44 arguments that draw on appeals to pathos argue that the UN will be "weakened" should it not enforce Security Council resolutions: he asks "What would any tyrannical regime possessing WMD think viewing the history of the world's diplomatic dance with Saddam? That our capacity to pass firm resolutions is matched only by our fear in implementing them". Such a condemnation alludes to the risks involved in limiting the UN's scope of action - namely, that other "tyrannical regimes" could follow the same path that has led Hussein to, ostensibly, challenge the western world. Blair continues this line later in his speech, openly articulating this same danger:

To retreat now, I believe, would put at hazard all that we hold dearest, turn the UN back into a talking shop, stifle the first steps of progress in the Middle East, leave the Iraqi people at the mercy of events on which we would have relinquished all power to influence for the better.

By stating both the political and military threats posed by regimes which undermine and threaten western democracies, Blair gives his audience multiple reasons to reconsider any reluctance in supporting the United States.

Blair further works to discredit Hussein as an authoritative political figure by referring to him by his first name rather than his last ("What will Saddam feel?"). In doing this, Blair diminishes, even denies, conferring upon Hussein the authority that he

\footnotetext{
${ }^{9}$ Full text and analysis of Blair's speech may be found in Appendix C, Article 3 and 4.
} 
would otherwise command as a political leader. In this way, Blair, like Bush, "frames" the way in which his audience perceives Hussein - as an illegitimate dictator, rather than as a valid authority.

Blair uses rhetorical questions to great effect in providing readers with propagandistic instances of "Grim Generality”. By asking his audience to imagine their own (vision of a world where Hussein has won), Blair turns the argument from an objective debate into a personal issue.

A final point of note in analyzing Blair's use of emotional appeals is the way in which he argues the wide-ranging implications of allowing Iraq to "flout" UN authority. Rather than focusing on domestic concerns and issues as Bush does, Blair emphasizes the threat that Hussein's actions pose to the wider world, pointing to both the UN and western values as targets of terrorist aggression. He speaks of how terrorism "poisons the chances of political progress" in the Middle East and Africa, and of how terrorists, aided by Iraq, "detest the freedom, democracy and tolerance that are the hallmarks of our way of life". In giving the "threat" a global focus, Blair effectively broadens the scope of the debate, enabling his audience to picture the threat as an ideological assault on western civilization as a whole. Sixty-eight percent of Blair's appeals to pathos in this speech constitute propaganda as defined by Elspeth Tilley's Propaganda Index; of that, twelve appeals to pathos refer to the threat of weakening the UN, with ten of those appeals constituting propaganda. ${ }^{10}$

Stephen Harper's Speech to the House of Commons, given on 20 March, 2003, encompasses many of the same arguments used by Blair and Bush. Indeed, the three speakers use extremely similar discursive phrases through the course of their speeches,

\footnotetext{
${ }^{10}$ The results of Blair's analysis in the Propaganda Index may be found in Appendix C, Article 3.
} 
which, I believe, contributes to the comparable levels of propaganda as defined by Tilley in each. Like Bush, Harper articulates the threat of Hussein and other "tyrannical regimes" in possession of WMDs, and, like Blair, he discusses the dangers of weakening the UN. Harper's most prominent argument, however, pertains to the diplomatic danger of Canada "abandoning" the United States. In not supporting the United States, Harper argues, Canada would "inevitably undermine one of the most important relationships that we have" and risk abandoning "our British and American allies in their time of need."11

Harper makes use of some arguments that Tilley would consider propaganda on the basis of her Index, but which do not use appeals to pathos in order to persuade audiences. For example, his allusion to Operation Desert Fox as a successful military campaign against Iraq would be considered an example of Transfer Positive; ${ }^{12}$ however, as the argument does not make use of pathos as outlined in the Pathos Code, I chose not to include it in my final analysis (Appendix D, Article 6, point 15).

As the voice of dissent for a government that had already chosen not to join the "Coalition of the Willing," Harper's message differs slightly from Blair's . Unlike Blair, Harper speaks for the opposition party in the Canadian government and is voicing his support for the United States after the Canadian government has already decided not to join. As a result, his speech is heavily critical of the majority government. He makes very effective use of Tilley's propagandistic categories Plain Folks and Name Calling to alienate his political opponents, condemning both the Parti Quebecois's and the Liberal

\footnotetext{
${ }^{11}$ The full text and analysis of Harper's Speech to the House of Commons may be found in Appendix D, Article 5 and 6.

${ }^{12}$ Transfer Positive, as defined by Tilley: "Process of association whereby the 'good' of one thing rubs off onto something else (e.g., through appropriation of symbolic objects such as national flags or anthem, sponsorship, celebrity or 'expert' endorsement)".
} 
government's "abandonment" of Canada's traditional "values and vision". Harper's use of Name Calling and Plain Folks tactics against his political adversaries enable him to nominally discredit the anti-war stance of his political adversaries, thereby presenting his summary of the issue as the only "logical" one to consider. A particularly effective example of such Name Calling rhetorically aligns the Liberal majority government with Hussein's regime: after accusing Hussein of "play[ing] a game of cat and mouse", he accuses the Liberal government of "playing irrelevant and contradictory games". In doing this, Harper implicitly aligns the two groups, thereby reinforcing the inherent "reasonableness" of the point of view that he offers.

Harper's speech contains 22 arguments that make use of appeals to pathos. Of these 16 , or $73 \%$, constitute propaganda as defined by Tilley. ${ }^{13}$ Many of Harper's appeals to pathos closely echo those used by Bush and Blair - a similarity to be expected, given the context and subject matter in question. Like Bush and Blair, Harper refers to the "hatred" and "detestation" that Iraqi terrorists have for Western civilization; he discusses the looming "threat" posed by rebel regimes in possession of WMDs, and paints a picture of the eventual "liberation" of the Iraqi people from the "tyranny" that oppresses them. Harper and Blair both state that "force" is the only language that Hussein understands and refer to the "games" played by Hussein in flouting UN resolutions, while Bush and Harper both allude to the global justice that will be served by the removal of Saddam Hussein. ${ }^{14}$

\footnotetext{
${ }^{13}$ Full details may be found in Appendix D, Article 5.

${ }^{14}$ Please refer to Appendix A, Table 3.
} 


\section{CONCLUSION}

This study examined war justification speeches given by pro-war leaders on the eve of the Iraq invasion. These speeches allowed Bush, Blair and Harper to "frame" aspects of the diplomatic context that surrounded the issue at the time: their use of emotional appeals greatly influenced how the war was perceived by domestic audiences, many of whom, as a result of such discourse, believed that Iraq possessed weapons of mass destruction intended to be used in attacks on the western world. By providing audiences with a particular framework within which to perceive the conflict, these political speakers actively manipulated how their audience viewed it - but is this unethical, or merely a necessary function of political speech as a whole? The question turns on the idea of political "truth" as an intangible or subjective concept - yet political ideology cannot be a defense against unethical discursive practices.

My research questions focused my inquiry into looking at how truth and ethics played out in my data set. As an integral and classically grounded part of rhetoric as a whole, appeals to emotion, or pathos, can be effective and legitimate components of a well-rounded rhetorical argument. The defining line between a legitimate appeal to emotion and "propaganda" as negative emotional manipulation lies in the context surrounding the appeal itself: that is, legitimate appeals to pathos occur when a speaker has provided audiences with enough evidence to enable them to make an objectively informed opinion on the issue at hand. More simply put, when emotional appeals are used to obscure or distort truth, they are illegitimate. In political contexts, however, "objectivity" or "truth" is often driven by political ideology. Thus, remaining aware of 
bias and recognizing when it is and is not an appropriate part of political discourse, may help audiences make informed opinions.

This point leads me to address bias in this paper. While I attempted to remain objective through the course of my analysis, some degree of bias is inevitable in researching political case studies. By remaining aware of this possibility and editing specifically for bias, I believe that I have accomplished a largely objective analysis of political persuasion.

Like so many before me, I believe that that which asks us to question political communication is highly important to the political process. Studies such as these which expose the extent to which propaganda may be a part of political speech help to draw back the veil and remind us of why being engaged and informed is such an essential part of our social responsibilities. Rhetoric is a tool, yes - but by knowing how to use it ethically, and by seeing where persuasion can transform into propaganda, we, as an audience, can be critical consumers, rather than passive observers, of the political agenda. 


\section{Appendix A}

Table I

\section{Pathos Code: Appeals to Pathos Analytic Categories and Descriptions}

\begin{tabular}{|c|c|c|c|}
\hline Category & Definition & Key Words & Example \\
\hline $\begin{array}{l}\text { Threat To National } \\
\text { and/or Global } \\
\text { Welfare }\end{array}$ & $\begin{array}{l}\text { Emphasis upon } \\
\text { nationalistic/patriotic } \\
\text { sympathies; suggestion of } \\
\text { imminent threat to the nation } \\
\text { or to the world at large. } \\
\text { Includes references to } \\
\text { "protect[ing]" the "nation", } \\
\text { "world" / "national interests", } \\
\text { "global security" against "enemy } \\
\text { invasions." Invokes need to } \\
\text { "defend" the homeland or } \\
\text { western way of life. }\end{array}$ & $\begin{array}{l}\text { "nation" } \\
\text { "security" } \\
\text { "interests" } \\
\text { "defense" } \\
\text { "global interest" }\end{array}$ & $\begin{array}{l}\text { "In desperation, [Hussein] and terrorist } \\
\text { groups might try to conduct terrorist } \\
\text { operations against the American } \\
\text { people and our friends" (Bush, Message } \\
\text { to Saddam) }\end{array}$ \\
\hline $\begin{array}{l}\text { Fear and Urgency } \\
\text { Appeals }\end{array}$ & $\begin{array}{l}\text { Emphasis upon the need for } \\
\text { immediate offensive action. } \\
\text { Invokes sense of time "ticking } \\
\text { down" to impending "doom" or } \\
\text { "terror"; speculation of dangers } \\
\text { yet to come and need to meet } \\
\text { them }\end{array}$ & $\begin{array}{l}\text { "threat" } \\
\text { "doom" } \\
\text { "horror" } \\
\text { "pain" } \\
\text { "now" } \\
\text { "immediate" } \\
\text { "danger" }\end{array}$ & $\begin{array}{l}\text { "Before the day of horror can come, } \\
\text { before it is too late to act, this } \\
\text { danger will be removed ... We choose to } \\
\text { meet that threat now, where it arises, } \\
\text { before it can appear suddenly in our } \\
\text { skies." (Bush, Message to Saddam" }\end{array}$ \\
\hline $\begin{array}{l}\text { Vilification of } \\
\text { "Other" }\end{array}$ & $\begin{array}{l}\text { Projection of negative or } \\
\text { aggressive tendencies and biases } \\
\text { upon the "enemy" or } \\
\text { "unsupportive" UN member } \\
\text { states. Use of politically charged } \\
\text { terms and labels to refer to or } \\
\text { imply that the "other" is the } \\
\text { "enemy" or resistant to the } \\
\text { "needs" of the world }\end{array}$ & $\begin{array}{l}\text { "hate" } \\
\text { "evil" } \\
\text { "terrorist" } \\
\text { "dictator" }\end{array}$ & $\begin{array}{l}\text { "Looking back over the last twelve years, } \\
\text { we have been victims of our own desire to } \\
\text { placate the implacable ... To hope that } \\
\text { there was some genuine intent to do good } \\
\text { in a regime whose mind is in fact } \\
\text { evil." (Blair, Speech to the House of } \\
\text { Commons") }\end{array}$ \\
\hline Historical Allusion & $\begin{array}{l}\text { References to: } \\
\text { (a) prior dictatorships, } \\
\text { authoritarian regimes } \\
\text { or international } \\
\text { conflicts } \\
\text { (b) September I th } \\
\text { attacks on Twin } \\
\text { Towers } \\
\text { Invocation of specific emotional } \\
\text { response in audience that } \\
\text { connects current situation to } \\
\text { past injustices }\end{array}$ & $\begin{array}{l}\text { "Hitler" } \\
\text { "authoritarian" } \\
\text { "dictatorship" } \\
\text { "September I I } \\
\text { attacks" }\end{array}$ & $\begin{array}{l}\text { (a) "In the great wars of the last } \\
\text { century, against authoritarianism, } \\
\text { against fascism, against communism, } \\
\text { Canada did not merely stand with the } \\
\text { Americans, we, more often than not, led } \\
\text { the way" (Harper, Speech to House of } \\
\text { Commons) } \\
\text { (b) "Leaving Saddam Hussein in possession } \\
\text { of weapons of mass destruction for a few } \\
\text { more months or years is not an option, } \\
\text { not in a post-September I Ith } \\
\text { world." (Colin Powell, Speech to the UN) }\end{array}$ \\
\hline Fate of Iraq & $\begin{array}{l}\text { Condemnation of the injustices } \\
\text { against Iraqi people; invoke } \\
\text { feeling of outrage or injustice in } \\
\text { audience, encourage need to } \\
\text { intervene and provide "noble" } \\
\text { assistance. Expression of future } \\
\text { potential of Iraq if "freed" from } \\
\text { the "oppression" of current } \\
\text { regime }\end{array}$ & $\begin{array}{l}\text { "oppression" } \\
\text { "brutality" } \\
\text { "torture" } \\
\text { "suffering" } \\
\text { "liberation" }\end{array}$ & $\begin{array}{l}\text { "The brutality of the repression [of the } \\
\text { Iraqi people] - the death and torture } \\
\text { camps, the barbaric prisons for political } \\
\text { opponents, the routine beatings for anyone } \\
\text { or their families suspected of disloyalty ..." } \\
\text { (Blair, Speech to House of Commons) }\end{array}$ \\
\hline
\end{tabular}


Table 2

\section{Propaganda Index}

\begin{tabular}{|c|c|}
\hline Device & Description \\
\hline Name Calling & $\begin{array}{l}\text { Negative or "bad" labels or stereotypes (e.g. terrorists, extremists, fanatics, } \\
\text { ferals, "rent-a-crowd") that encourage a summary negative response without } \\
\text { examining history, complexity, or evidence related to an issue }\end{array}$ \\
\hline Glittering Generality & $\begin{array}{l}\text { Abstract positive labeling using virtue connotators (e.g., intelligence for covert } \\
\text { surveillance); positive-sounding euphemisms (e.g., collateral damage and } \\
\text { friendly fire for civilian or own-troop deaths; biosolids for sewerage); broadly } \\
\text { affirmative unverifiable adjectives (e.g., state-of-the-art, high-tech); positive } \\
\text { abstractions (e.g., prosperity, freedom, rights, democracy, respect, common } \\
\text { sense); vagaries (e.g., significantly increasing or highly trained, where the level } \\
\text { of increase or training is not defined); subjective adjectives or adverbs } \\
\text { (beautiful, stunning) which give positive effect without evidence }\end{array}$ \\
\hline Transfer Positive & $\begin{array}{l}\text { Process of association whereby the "good" of one thing rubs off onto } \\
\text { something else (e.g., through appropriation of symbolic objects such as } \\
\text { national flags or anthem, sponsorship, celebrity or "expert" endorsement) }\end{array}$ \\
\hline Transfer Negative & $\begin{array}{l}\text { Express or implied association with negative incidents, places, people or } \\
\text { symbols to "rub off" negative qualities to the issue being discussed or } \\
\text { discredit by implication an opposing viewpoint (e.g. may have links with Al } \\
\text { Qaida, has been seen in the company of known terrorists, etc.) }\end{array}$ \\
\hline Plain Folks & $\begin{array}{l}\text { Implication that ideas are "of the people" (e.g., references to family values, } \\
\text { hard working, decent folk, normal people, or middle Australia). PF is a values- } \\
\text { based device that implies normalcy or rationality for an opinion and thereby } \\
\text { demonizes other views as aberrant and unreasonable, even if they are } \\
\text { majority }\end{array}$ \\
\hline Band Wagon & $\begin{array}{l}\text { Peer pressure or spiral of silence device (e.g., implication that everyone, most } \\
\text { people, many people or any large collectivized group of people such as our } \\
\text { school, our company, or our neighbourhood thinks a particular, singular and } \\
\text { uniform way). Includes references to imagined communities such as states, } \\
\text { nations, organizations, and phrases such as we, our, all, everybody that invite } \\
\text { solidarity with an implied large and inclusive group, suggest mass support for } \\
\text { an opinion, marginalize alternative views as minority, suggest collective } \\
\text { ownership of and responsibility for the actions of a group (e.g., "our army") } \\
\text { or obscure internal division within a group }\end{array}$ \\
\hline Manifest Destiny & $\begin{array}{l}\text { Deterministic invocation of God (of any kind or faith), destiny, fate, natural } \\
\text { processes, or universal design, to lend support to an argument; removal of } \\
\text { accountability for an idea or issue from individuals and attribution of } \\
\text { responsibility to deterministic "greater forces" (God's will, karma, tradition, } \\
\text { luck, History, Nature) }\end{array}$ \\
\hline Other & $\begin{array}{l}\text { A phrase that appears either neutral, with no rhetorical or persuasive effect, } \\
\text { or persuasive but does not fit into any of the above categories }\end{array}$ \\
\hline
\end{tabular}

Courtesy of Elspeth Tilley (2005): Responding to Terrorism Using Ethical Means: The Propaganda Index. Communication Research Reports, 22.I p. 69-77

Table 2(a)

\section{PROPAGANDA INDEX MODIFICATION}

\begin{tabular}{|l|l|}
\hline Device & Description \\
\hline Grim Generality & $\begin{array}{l}\text { Abstract negative labeling using vice connotators; negative-sounding euphemisms; } \\
\text { broadly negative unverifiable adjectives (e.g., danger, chaos); vague speculation of } \\
\text { negative eventualities (e.g., "should our enemies strike"); negative abstractions (e.g., } \\
\text { evil, danger, immoral); subjective adjectives or adverbs which give negative effect } \\
\text { without evidence }\end{array}$ \\
\hline
\end{tabular}


Table 3

Rhetorical Similarities in Bush, Blair and Harper Speeches

\begin{tabular}{|c|c|c|}
\hline Bush & Blair & Harper \\
\hline \multirow{2}{*}{$\begin{array}{l}\text { "As we honour the just demands } \\
\text { of the world" }\end{array}$} & & "The world has judged" \\
\hline & $\begin{array}{l}\text { "...it is dangerous. It is dangerous } \\
\text { if such regimes disbelieve us" }\end{array}$ & "...it is inherently dangerous" \\
\hline $\begin{array}{l}\text { "The Iraqi regime has uniformly } \\
\text { defied Security Council } \\
\text { resolutions demanding full } \\
\text { disarmament" }\end{array}$ & $\begin{array}{l}\text { "in that hesitation he senses the } \\
\text { weakness and therefore } \\
\text { continues to defy" }\end{array}$ & $\begin{array}{l}\text { "...continue to defy international } \\
\text { resolutions" }\end{array}$ \\
\hline $\begin{array}{l}\text { "We choose to meet that threat } \\
\text { now" }\end{array}$ & "The threat is chaos." & $\begin{array}{l}\text { "...direct, undeniable, lethal } \\
\text { threat" }\end{array}$ \\
\hline $\begin{array}{l}\text { "It has a deep hatred of America } \\
\text { and our friends" }\end{array}$ & $\begin{array}{l}\text { "They detest the freedom, } \\
\text { democracy and tolerance that } \\
\text { are the hallmarks of our way of } \\
\text { life" }\end{array}$ & $\begin{array}{l}\text { "...hatred they direct toward us } \\
\text { and our civilization" }\end{array}$ \\
\hline $\begin{array}{l}\text { "The US did nothing to deserve } \\
\text { or invite this threat" }\end{array}$ & $\begin{array}{l}\text { "and when the threat returns } \\
\text { from Iraq or elsewhere, who will } \\
\text { believe us? }\end{array}$ & $\begin{array}{l}\text { "we cannot walk away from the } \\
\text { threat" }\end{array}$ \\
\hline \multirow[t]{2}{*}{$\begin{array}{l}\text { "Peaceful efforts to disarm the } \\
\text { Iraqi regime have failed again and } \\
\text { again - because we are not } \\
\text { dealing with peaceful men" }\end{array}$} & $\begin{array}{l}\text { "What changed his mind? The } \\
\text { threat of force. And what makes } \\
\text { him now issue invitations to the } \\
\text { inspectors, discover documents } \\
\text { he said he never had, produce } \\
\text { evidence of weapons supposed } \\
\text { to be non-existent, destroy } \\
\text { missiles he said he would keep? } \\
\text { The imminence of force" }\end{array}$ & $\begin{array}{l}\text { "Force has been the only } \\
\text { language Saddam has ever } \\
\text { understood" }\end{array}$ \\
\hline & $\begin{array}{l}\text { "To retreat now, I believe, would } \\
\text { put at hazard all that we hold } \\
\text { dearest, turn the UN back into a } \\
\text { talking shop..." }\end{array}$ & $\begin{array}{l}\text { "to do so will inevitably } \\
\text { undermine one of the most } \\
\text { important relationships we have" }\end{array}$ \\
\hline "The tyrant will soon be gone" & $\begin{array}{l}\text { "We will confront the tyrannies } \\
\text { and dictatorships and terrorists } \\
\text { who put our way of life at risk" }\end{array}$ & $\begin{array}{l}\text { "His final bloody chapter is being } \\
\text { read" }\end{array}$ \\
\hline $\begin{array}{l}\text { "The day of your liberation is } \\
\text { near" }\end{array}$ & $\begin{array}{l}\text { "... the Iraqi people, whose only } \\
\text { true hope of liberation lies in the } \\
\text { removal of Saddam" }\end{array}$ & $\begin{array}{l}\text { "We will pray for the liberation } \\
\text { of the people of Iraq" }\end{array}$ \\
\hline
\end{tabular}




\section{Appendix "B"}

Article I

Analysis: George W Bush's "Message to Saddam"

Analysis Summary

Propaganda in "Message to Saddam"

Total arguments that use appeals to pathos in Message to Saddam: 26

Total legitimate appeals to pathos: 5

Total illegitimate appeals to pathos: 21

Propaganda Percentage: $81 \%$

Applied Pathos Code Legend

\begin{tabular}{|l|l|}
\hline Code Colour & Appeal Category \\
\hline Red & Threat to Global/National Welfare \\
\hline Orange & Fear and Urgency Appeals \\
\hline Green & Vilification of the "Other” \\
\hline Pink & $\begin{array}{l}\text { Historical Allusion “A” (prior dictatorships/international } \\
\text { struggles) }\end{array}$ \\
\hline Purple & $\begin{array}{l}\text { Historical Allusion “B” (September I I attacks on Twin } \\
\text { Towers" }\end{array}$ \\
\hline Blue & Fate of Iraqi People \\
\hline
\end{tabular}




\section{Article 2 \\ George W Bush's “Message To Saddam” Analyzed by Argument}

\begin{tabular}{|c|c|c|c|c|}
\hline & Summary & Passage & Identified Appeals to Pathos & $\begin{array}{l}\text { Propaganda Index / } \\
\text { Justification }\end{array}$ \\
\hline I & $\begin{array}{l}\text { We have tried } \\
\text { peaceful } \\
\text { resolutions, but } \\
\text { must act now }\end{array}$ & $\begin{array}{l}\text { My fellow citizens, events in Iraq have now reached the } \\
\text { final days of decision. For more than a decade, the } \\
\text { United States and other nations have pursued patient and } \\
\text { honorable efforts to disarm the Iraqi regime without war. } \\
\text { That regime pledged to reveal and destroy all its } \\
\text { weapons of mass destruction as a condition for ending } \\
\text { the Persian Gulf War in I99I. } \\
\text { Since then, the world has engaged in } 12 \text { years of } \\
\text { diplomacy. We have passed more than a dozen } \\
\text { resolutions in the United Nations Security Council. We } \\
\text { have sent hundreds of weapons inspectors to oversee } \\
\text { the disarmament of Iraq. Our good faith has not been } \\
\text { returned. }\end{array}$ & $\begin{array}{l}\text { Fear/Urgency Appeal } \\
\text { Vilification of the "Other" } \\
\text { Intent: To demonstrate that US has } \\
\text { acted with "good faith" but that Iraq } \\
\text { has not responded in kind; stress } \\
\text { upon the need to act because all } \\
\text { alternative measures have been } \\
\text { tried. }\end{array}$ & $\begin{array}{l}\text { Not Propaganda: It } \\
\text { "frames"/provides } \\
\text { context to the question } \\
\text { of Iraq possessing WMD, } \\
\text { but does not make } \\
\text { untoward allegations } \\
\text { against the regime }\end{array}$ \\
\hline 3 & $\begin{array}{l}\text { Iraq possesses and } \\
\text { has already used } \\
\text { WMD's against } \\
\text { their enemies }\end{array}$ & $\begin{array}{l}\text { Intelligence gathered by this and other governments } \\
\text { leaves no doubt that the Iraq regime continues to } \\
\text { possess and conceal some of the most lethal weapons } \\
\text { ever devised. This regime has already used weapons of } \\
\text { mass destruction against Iraq's neighbours and against } \\
\text { Iraqi's people. }\end{array}$ & $\begin{array}{l}\text { Fear/Urgency Appeal } \\
\text { Vilification of the "Other" } \\
\text { Intent: Uses strong language to } \\
\text { stress importance of the issue and } \\
\text { frames Iraq's possession of WMD as } \\
\text { a global concern. Demonstrates } \\
\text { Iraq's propensity for using WMDs }\end{array}$ & $\begin{array}{l}\text { Grim Generality: } \\
\text { Unverifiable accusation of } \\
\text { Iraq possessing these } \\
\text { "most lethal" weapons; } \\
\text { no concrete examples } \\
\text { given of Iraq using them } \\
\text { against neighbours or } \\
\text { own people. }\end{array}$ \\
\hline 5 & $\begin{array}{l}\text { Iraq could help } \\
\text { terrorists attack the } \\
\text { United States }\end{array}$ & $\begin{array}{l}\text { The danger is clear: using chemical, biological, or, one } \\
\text { day, nuclear weapons obtained with the help of Iraq, } \\
\text { terrorists could fulfill their stated ambitions and kill } \\
\text { thousands or hundreds of thousands of innocent people } \\
\text { in our country, or any other. }\end{array}$ & $\begin{array}{l}\text { Threat to Global/National Welfare } \\
\text { Fear/Urgency Appeal } \\
\text { Intent: Provide "worst-case } \\
\text { scenario" to audiences involving the } \\
\text { danger of allowing Iraq to possess } \\
\text { WMDs }\end{array}$ & $\begin{array}{l}\text { Grim Generality: } \\
\text { Worst-case-scenario } \\
\text { given to audiences in } \\
\text { extremely graphic } \\
\text { language } \\
\text { Transfer Negative: } \\
\text { Aligns Iraq with } \\
\text { terrorists in definitive, } \\
\text { collusive terms }\end{array}$ \\
\hline 6 & $\begin{array}{l}\text { The United States } \\
\text { must fight against } \\
\text { this potential future }\end{array}$ & $\begin{array}{l}\text { The United States and other nations did nothing to } \\
\text { deserve or invite this threat. But we will do everything } \\
\text { to defeat it. Instead of drifting along toward tragedy, we } \\
\text { will set a course toward safety. Before the day of horror } \\
\text { can come, before it is too late to act, this danger will be } \\
\text { removed. }\end{array}$ & $\begin{array}{l}\text { Threat to Global/National Welfare } \\
\text { Fear/Urgency Appeal } \\
\text { Intent: Underline need to act } \\
\text { immediately, before aggressor has } \\
\text { the chance to bring "horror" upon } \\
\text { American people }\end{array}$ & $\begin{array}{l}\text { Grim Generality: } \\
\text { Stresses need to } \\
\text { counteract the broadly } \\
\text { general picture of a "day } \\
\text { of horror" to provoke } \\
\text { fear in audience }\end{array}$ \\
\hline
\end{tabular}




\begin{tabular}{|c|c|c|c|c|}
\hline 7 & $\begin{array}{l}\text { USA has the } \\
\text { authority to use } \\
\text { force in assuring } \\
\text { national security }\end{array}$ & $\begin{array}{l}\text { The United Sates of America has the sovereign authority } \\
\text { to use force in assuring its own national security. That } \\
\text { duty falls to me, as Commander-in-Chief, by the oath I } \\
\text { have sworn, by the oath I will keep. }\end{array}$ & $\begin{array}{l}\text { Threat to Global/National Welfare } \\
\text { Assertion of speaker's authority to } \\
\text { authorize attack on Iraq } \\
\text { Intent: Provide justification for } \\
\text { declaration of invasion }\end{array}$ & $\begin{array}{l}\text { Not Propaganda: } \\
\text { Statement of fact }\end{array}$ \\
\hline 8 & $\begin{array}{l}\text { USA has tried to } \\
\text { work with UN to } \\
\text { resolve issue }\end{array}$ & $\begin{array}{l}\text { Recognizing the threat to our country, the United States } \\
\text { Congress voted overwhelmingly last year to support the } \\
\text { use of force against Iraq. America tried to work with the } \\
\text { United Nations to address this threat because we wanted } \\
\text { to resolve the issue peacefully. We believe in the } \\
\text { mission of the United Nations. One reason the UN was } \\
\text { founded after the Second World War was to confront } \\
\text { aggressive dictators, actively and early, before they can } \\
\text { attack the innocent and destroy peace. }\end{array}$ & $\begin{array}{l}\text { Threat to Global/National Welfare } \\
\text { Historical Allusion "A" (prior } \\
\text { dictatorships) } \\
\text { Intent: Draw upon authority of UN } \\
\text { as international peacekeeper; discuss } \\
\text { prior attempts to resolve issue } \\
\text { peacefully; align Hussein with other } \\
\text { "aggressive dictators" that UN has } \\
\text { dealt with }\end{array}$ & $\begin{array}{l}\text { Transfer Negative: } \\
\text { Implicitly align Hussein } \\
\text { with other "aggressive } \\
\text { dictators" to justify } \\
\text { UN/US intervention }\end{array}$ \\
\hline 9 & $\begin{array}{l}\text { UN gave USA } \\
\text { authority to force } \\
\text { Iraq to disarm }\end{array}$ & $\begin{array}{l}\text { In the case of Iraq, the Security Council did act, in the } \\
\text { early I } 990 \text { s. Under Resolutions } 678 \text { and } 687 \text { - both still } \\
\text { in effect - the United States and our allies are authorized } \\
\text { to use force in ridding Iraq of weapons of mass } \\
\text { destruction. This is not a question of authority, it is a } \\
\text { question of will. } \\
\text { Last September, I went to the UN General Assembly and } \\
\text { urged the nations of the world to unite and bring an end } \\
\text { to this danger. On November } 8^{\text {th }} \text {, the Security Council } \\
\text { unanimously passed Resolution I } 44 \text { I, finding Iraq in } \\
\text { material breach of its obligations, and vowing serious } \\
\text { consequences if Iraq did not fully and immediately disarm. }\end{array}$ & $\begin{array}{l}\text { Threat to Global/National Welfare } \\
\text { Intent: Argue that USA is drawing } \\
\text { upon previous authority granted to } \\
\text { compel disarming of Iraq ; } \\
\text { demonstrate the unity of Security } \\
\text { Council in condemning Iraq's actions }\end{array}$ & $\begin{array}{l}\text { Not Propaganda: } \\
\text { Statement of action }\end{array}$ \\
\hline 10 & $\begin{array}{l}\text { Iraq will not } \\
\text { voluntarily disarm }\end{array}$ & $\begin{array}{l}\text { Today, no nation can possibly claim that Iraq has } \\
\text { disarmed. And it will not disarm so long as Saddam } \\
\text { Hussein holds power. }\end{array}$ & $\begin{array}{l}\text { Fear/Urgency Appeal } \\
\text { Vilification of the "Other" } \\
\text { Intent: Point out need to disarm Iraq } \\
\text { without Hussein's cooperation; unity } \\
\text { of countries in agreeing that Iraq has } \\
\text { not disarmed }\end{array}$ & $\begin{array}{l}\text { Band Wagon: } \\
\text { Reference to "all nations" } \\
\text { as in unanimous } \\
\text { agreement about Iraq's } \\
\text { actions }\end{array}$ \\
\hline 12 & $\begin{array}{l}\text { We have allies who } \\
\text { support what we } \\
\text { are doing }\end{array}$ & $\begin{array}{l}\text { Many nations, however, do have the resolve and the } \\
\text { fortitude to act against this threat to peace, and a broad } \\
\text { coalition is now gathering to enforce the just demands of } \\
\text { the world. The United Nations Security Council has not } \\
\text { lived up to its responsibilities, so we will rise to ours. }\end{array}$ & $\begin{array}{l}\text { Threat to Global/National Welfare } \\
\text { Vilification of the "Other" } \\
\text { Intent: Show that it is a global threat } \\
\text { and that USA is not alone in acting } \\
\text { against Iraq; justify why the USA } \\
\text { must act outside the UN Security } \\
\text { Council; legitimize US actions by } \\
\text { alluding to allies }\end{array}$ & $\begin{array}{l}\text { Plain Folks: Implication } \\
\text { that UN is "shirking" its } \\
\text { responsibilities and } \\
\text { duties; a values-based } \\
\text { criticism of Security } \\
\text { Council actions }\end{array}$ \\
\hline 13 & $\begin{array}{l}\text { Middle East } \\
\text { governments also } \\
\text { recognize the } \\
\text { threat posed by } \\
\text { Hussein }\end{array}$ & $\begin{array}{l}\text { In recent days, some governments in the Middle East } \\
\text { have been doing their part. They have delivered public } \\
\text { and private messages urging the dictator to leave Iraq, so } \\
\text { that disarmament can proceed peacefully. He has thus } \\
\text { far refused. }\end{array}$ & $\begin{array}{l}\text { Vilification of the "Other" } \\
\text { Intent: Show that Middle East } \\
\text { countries likewise support US intent } \\
\text { to rid Iraq of the "dictator" }\end{array}$ & $\begin{array}{l}\text { Not Propaganda: } \\
\text { Statement of actions } \\
\text { taken by other countries }\end{array}$ \\
\hline
\end{tabular}




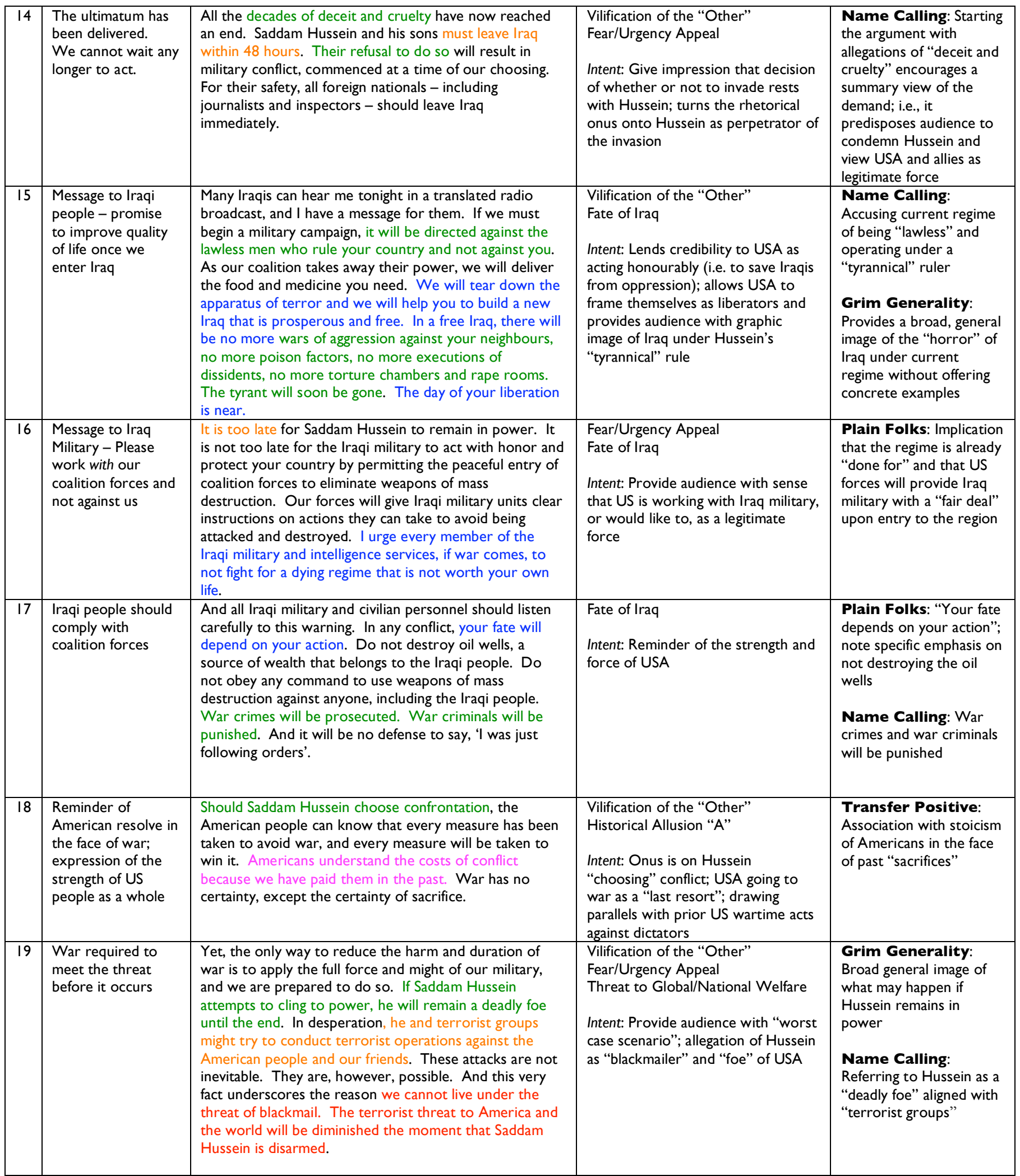




\begin{tabular}{|c|c|c|c|c|}
\hline 20 & $\begin{array}{l}\text { America is taking } \\
\text { steps to protect } \\
\text { itself against } \\
\text { enemies }\end{array}$ & $\begin{array}{l}\text { Our government is on heightened watch against these } \\
\text { dangers. Just as we are preparing to ensure victory in } \\
\text { Iraq, we are taking further actions to protect our } \\
\text { homeland. In recent days, American authorities have } \\
\text { expelled from the country certain individuals with ties to } \\
\text { Iraqi intelligence services. Among other measures, I have } \\
\text { directed additional security of our airports, and increased } \\
\text { Coast Guard patrols of major seaports. The Department } \\
\text { of Homeland Security is working closely with the nation's } \\
\text { governors to increase armed security at critical facilities } \\
\text { across America. }\end{array}$ & $\begin{array}{l}\text { Threat to Global/National Welfare } \\
\text { Intent: Reassure audiences that } \\
\text { steps are being taken to ensure } \\
\text { national security }\end{array}$ & $\begin{array}{l}\text { Not Propaganda: } \\
\text { Provides examples of } \\
\text { steps being taken }\end{array}$ \\
\hline 21 & $\begin{array}{l}\text { Qualification that } \\
\text { attacks are possible }\end{array}$ & $\begin{array}{l}\text { Should enemies strike our country, they would be } \\
\text { attempting to shift our attention with panic and weaken } \\
\text { our morale with fear. In this, they would fail. No act of } \\
\text { theirs can alter the course or shake the resolve of this } \\
\text { country. We are a peaceful people - yet we're not a } \\
\text { fragile people, and we will not be intimidated by thugs } \\
\text { and killers. If our enemies dare strike us, they and all } \\
\text { who have aided them, will face fearful consequences. }\end{array}$ & $\begin{array}{l}\text { Fear/Urgency Appeal } \\
\text { Vilification of the "Other" } \\
\text { Intent: Upset potential } \\
\text { complacencies; provide strong } \\
\text { rhetoric of united country }\end{array}$ & $\begin{array}{l}\text { Bandwagon: America } \\
\text { as united against an } \\
\text { external foe } \\
\text { Name Calling: } \\
\text { Enemies as a broad } \\
\text { category massing against } \\
\text { USA }\end{array}$ \\
\hline 23 & $\begin{array}{l}\text { Past shows that } \\
\text { allowing dictators } \\
\text { to grow in strength } \\
\text { is dangerous; new } \\
\text { realities underline } \\
\text { this fear }\end{array}$ & $\begin{array}{l}\text { The cause of peace requires all free nations to recognize } \\
\text { new and undeniable realities. In the } 20^{\text {th }} \text { century, some } \\
\text { chose to appease murderous dictators, whose threats } \\
\text { were allowed to grow into genocide and global war. In } \\
\text { this century, when evil men plot chemical, biological and } \\
\text { nuclear terror, a policy of appeasement could bring } \\
\text { destruction of a kind never before seen on this earth. }\end{array}$ & $\begin{array}{l}\text { Historical Allusion "A" } \\
\text { Vilification of the "Other" } \\
\text { Threat to Global/National Welfare } \\
\text { Fear/Urgency Appeal } \\
\text { Intent: Align Hussein with past } \\
\text { dictators and stress that the threat } \\
\text { he poses is even worse }\end{array}$ & $\begin{array}{l}\text { Grim Generality: } \\
\text { Very broad, very } \\
\text { extreme version of what } \\
\text { "appeasement" could } \\
\text { entail } \\
\text { Transfer Negative: } \\
\text { Association of Hussein } \\
\text { with } 20^{\text {th }} \text { century } \\
\text { dictators and allusion to } \\
\text { World War II }\end{array}$ \\
\hline 25 & $\begin{array}{l}\text { We will protect } \\
\text { Iraqi people and } \\
\text { allow them to } \\
\text { develop as a people } \\
\text { free from tyranny }\end{array}$ & $\begin{array}{l}\text { As we enforce the just demands of the world, we will } \\
\text { also honor the deepest commitments of our country. } \\
\text { Unlike Saddam Hussein, we believe the Iraqi people are } \\
\text { deserving and capable of human liberty. And when the } \\
\text { dictator has departed, they can set an example to all the } \\
\text { Middle East of a vital and peaceful and self-governing } \\
\text { nation. } \\
\text { The United States, with other countries, will work to } \\
\text { advance liberty and peace in that region. Our goal will } \\
\text { not be achieved overnight, but it can come over time. } \\
\text { The power and appeal of human liberty is felt in every life } \\
\text { and every land. And the greatest power of freedom is to } \\
\text { overcome hatred and violence, and turn the creative gifts } \\
\text { of men and women to the pursuits of peace. }\end{array}$ & $\begin{array}{l}\text { Fate of Iraq } \\
\text { Vilification of the "Other" } \\
\text { Intent: Show America as enforcer of } \\
\text { democratic ideals who will "save" } \\
\text { Iraqi people from dictator }\end{array}$ & $\begin{array}{l}\text { Band Wagon: "we" } \\
\text { are enforcing an ideal } \\
\text { that "we" know to be } \\
\text { just; "our" goal is one } \\
\text { that will come over time. } \\
\text { Very inclusive, general } \\
\text { statements of support } \\
\text { and ideology } \\
\text { Manifest Destiny: } \\
\text { Invocation of ideals of } \\
\text { human liberty and peace } \\
\text { to support US invasion of } \\
\text { Iraq }\end{array}$ \\
\hline
\end{tabular}




\section{BETWEEN RHETORIC AND PROPAGANDA}

\begin{tabular}{|l|l|l|l|l|}
\hline 26 & Conclusion & $\begin{array}{l}\text { That is the future we choose. Free nations have a duty } \\
\text { to defend our people by uniting against the violent. And } \\
\text { tonight, as we have done before, America and our allies } \\
\text { accept that responsibility. } \\
\text { Good night, and may God continue to bless America. }\end{array}$ & $\begin{array}{l}\text { Vilification of the "Other" } \\
\text { Fate of Iraq } \\
\text { Intent: Remind audience that the } \\
\text { "ultimate" reason for invading Iraq is } \\
\text { to support and protect the innocent } \\
\text { against the evil/violent }\end{array}$ & $\begin{array}{l}\text { Manifest Destiny: It } \\
\text { is the "future" and the } \\
\text { "responsibility" of } \\
\text { America to defend itself } \\
\text { and others against } \\
\text { tyranny }\end{array}$ \\
\end{tabular}




\title{
Appendix "C"
}

Article 3

\section{Analysis: Tony Blair's "Speech to the House of Commons"}

\author{
Analysis Summary \\ Propaganda in "Speech to the House of Commons" \\ Total arguments that use appeals to pathos in Speech to the House of Commons: 44 \\ Total legitimate appeals to pathos: 14 \\ Total illegitimate appeals to pathos: 30 \\ Propaganda Percentage: 68\%
}

Applied Pathos Code Legend

\begin{tabular}{|l|l|}
\hline Code Colour & Appeal Category \\
\hline Red & Threat to Global/National Welfare \\
\hline Orange & Fear and Urgency Appeals \\
\hline Green & Vilification of the "Other" \\
\hline Pink & $\begin{array}{l}\text { Historical Allusion “A” (prior dictatorships/international } \\
\text { struggles) }\end{array}$ \\
\hline Purple & $\begin{array}{l}\text { Historical Allusion “B” (September II attacks on Twin } \\
\text { Towers" }\end{array}$ \\
\hline Blue & Fate of Iraqi People \\
\hline
\end{tabular}




\section{Article 4 \\ Tony Blair's “Speech to the House of Commons" Analyzed by Argument}

\begin{tabular}{|c|c|c|c|c|}
\hline & Summary & Passage & Identified Appeals to Pathos & $\begin{array}{l}\text { Propaganda Index / } \\
\text { Justification }\end{array}$ \\
\hline $\mathrm{I}$ & $\begin{array}{l}\text { Opening: } \\
\text { Democracy must } \\
\text { be recognized as a } \\
\text { privilege that we } \\
\text { should respect }\end{array}$ & $\begin{array}{l}\text { I beg to move the motion standing on the order paper in } \\
\text { my name and those of my right honourable friends. At } \\
\text { the outset I say: it is right that this house debate this } \\
\text { issue and pass judgment. That is the democracy that is } \\
\text { our right but that others struggle for in vain. And again I } \\
\text { say: I do not disrespect the views of those in opposition } \\
\text { to mine. }\end{array}$ & $\begin{array}{l}\text { Intent: Remind audience of the } \\
\text { nature of democracy; imply that } \\
\text { others, such as those in Iraq to } \\
\text { whom he refers later in the speech, } \\
\text { do not share democratic rights as } \\
\text { audience does }\end{array}$ & Not Propaganda \\
\hline 2 & $\begin{array}{l}\text { We must have a } \\
\text { military presence } \\
\text { in Iraq }\end{array}$ & $\begin{array}{l}\text { This is a tough choice. But it is also a stark one: to stand } \\
\text { British troops down and turn back; or to hold firm to the } \\
\text { course we have set. I believe we must hold firm. }\end{array}$ & $\varnothing$ & $\varnothing$ \\
\hline 3 & & $\begin{array}{l}\text { The question most often posed is not why does it } \\
\text { matter, but why does it matter so much? Here we are, } \\
\text { the government with its most serious test, its majority at } \\
\text { risk, the first Cabinet resignation over an issue of policy. } \\
\text { The main parties divided. } \\
\text { People who agree on everything else disagree on this } \\
\text { and, likewise, those who never agree on anything find } \\
\text { common cause. The country and parliament reflect each } \\
\text { other, a debate that, as time as gone on has become less } \\
\text { bitter but not less grave. }\end{array}$ & $\varnothing$ & $\varnothing$ \\
\hline 4 & $\begin{array}{l}\text { These are all of } \\
\text { the factors that } \\
\text { depend upon the } \\
\text { decision made } \\
\text { today }\end{array}$ & $\begin{array}{l}\text { So: Why does it matter so much? Because the outcome } \\
\text { of this issue will now determine more than the fate of } \\
\text { the Iraqi regime and more than the future of the Iraqi } \\
\text { people, for so long brutalized by Saddam. It will } \\
\text { determine the way Britain and the world confront the } \\
\text { central security threat of the } 2 I^{\text {st }} \text { century; the } \\
\text { development of the UN; the relationship between } \\
\text { Europe and the US; the relations within the EU and the } \\
\text { way the US engages with the rest of the world. It will } \\
\text { determine the pattern of international politics for the } \\
\text { next generation. }\end{array}$ & $\begin{array}{l}\text { Fate of Iraq } \\
\text { Threat to Global/National Security } \\
\text { Vilification of the "Other" } \\
\text { Fear/Urgency Appeal } \\
\text { Intent: Underline the gravitas of the } \\
\text { issue and the wide-ranging } \\
\text { consequences of all decisions made. } \\
\text { Make audience recognize the } \\
\text { extreme importance of it outside } \\
\text { the realm of Hussein alone }\end{array}$ & $\begin{array}{l}\text { Manifest Destiny: } \\
\text { Deterministic portrayal } \\
\text { of the stakes of the issue } \\
\text { at hand }\end{array}$ \\
\hline 5 & $\begin{array}{l}\text { Historical } \\
\text { Overview (a) } \\
\text { I99I-I995 } \\
\text { Hussein had } \\
\text { already used } \\
\text { WMD and UN set } \\
\text { up inspections } \\
\text { process to } \\
\text { examine full extent } \\
\text { of Iraq's weapons } \\
\text { programme }\end{array}$ & $\begin{array}{l}\text { But first, Iraq and its WMD. } \\
\text { In April I99I, after the Gulf War, Iraq was given I5 days } \\
\text { to provide a full and final declaration of all its WMD. } \\
\text { Saddam had used the weapons against Iran, against his } \\
\text { own people, causing thousands of deaths. He had had } \\
\text { plans to use them against allied forces. It became clear } \\
\text { after the Gulf War that the WMD ambitions of Iraq were } \\
\text { far more extensive than hitherto thought. This issue was } \\
\text { identified by the UN as one for urgent remedy. Unscom, } \\
\text { the weapons inspections team, was set up. They were } \\
\text { expected to complete their task following the declaration } \\
\text { at the end of April I } 99 \text { I. } \\
\text { The declaration when it came was false - a blanket denial } \\
\text { of the programme, other than in a very tentative form. } \\
\text { So the I2-year game began. }\end{array}$ & $\begin{array}{l}\text { Vilification of the "Other" } \\
\text { Intent: Provide "character } \\
\text { reference" of Iraq's past actions and } \\
\text { its refusal to cooperate with UN }\end{array}$ & Not Propaganda \\
\hline
\end{tabular}




\section{BETWEEN RHETORIC AND PROPAGANDA}

\begin{tabular}{|c|c|c|c|c|}
\hline 6 & $\begin{array}{l}\text { Historical } \\
\text { Overview (b) } \\
\text { 1992-1994 } \\
\text { Iraq consistently } \\
\text { lied about } \\
\text { possessing WMD }\end{array}$ & $\begin{array}{l}\text { The inspectors probed. Finally in March 1992, Iraq } \\
\text { admitted that it had previously undeclared WMD but } \\
\text { said it had destroyed them. It gave another full and final } \\
\text { declaration. Again the inspectors probed but found little. } \\
\text { In October 1994, Iraq stopped cooperating with Unscom } \\
\text { altogether. Military action was threatened. Inspections } \\
\text { resumed. In March 1995, in an effort to rid Iraq of the } \\
\text { inspectors, a further full and final declaration of WMD } \\
\text { was made. By July 1995, Iraq was forced to admit that it } \\
\text { too was false. In August, they provided yet another full } \\
\text { and final declaration. }\end{array}$ & $\begin{array}{l}\text { Vilification of the "Other" } \\
\text { Intent: Provide content, but also } \\
\text { serves as a "character reference" to } \\
\text { Iraq and its actions }\end{array}$ & Not Propaganda \\
\hline 7 & $\begin{array}{l}\text { Historical } \\
\text { Overview (c) } \\
\text { Evidence provided } \\
\text { to show that } \\
\text { Hussein once again } \\
\text { lied about extent } \\
\text { of weapons } \\
\text { programme }\end{array}$ & $\begin{array}{l}\text { Then a week later, Saddam's son-in-law, Hussein Kamal, } \\
\text { defected to Jordan. He disclosed a far more extensive } \\
\text { BW (biological weapons) programme and for the first } \\
\text { time said Iraq had weaponised the programme; } \\
\text { something Saddam had always strenuously denied. All } \\
\text { this had been happening whilst the inspectors were in } \\
\text { Iraq. Kamal also revealed Iraq's crash programme to } \\
\text { produce a nuclear weapon in } 1990 \text {. } \\
\text { Iraq was then forced to release documents which } \\
\text { showed just how extensive those programmes were. In } \\
\text { 1995, Jordan intercepted prohibited components for } \\
\text { missiles that could be used for WMD. }\end{array}$ & $\begin{array}{l}\text { Vilification of the "Other" } \\
\text { Intent: Show that Iraq/Hussein was } \\
\text { demonstratively lying in the face of } \\
\text { witnesses; }\end{array}$ & $\begin{array}{l}\text { Not Propaganda } \\
\text { NOTE: use of Hussein's } \\
\text { first name, rather than } \\
\text { last name (unlike } \\
\text { Hussein's son, referred } \\
\text { to by last name) - } \\
\text { something Blair } \\
\text { continues to do } \\
\text { throughout the speech. } \\
\text { Diminishes Hussein's } \\
\text { authority in eyes of } \\
\text { audience. }\end{array}$ \\
\hline 8 & $\begin{array}{l}\text { Historical } \\
\text { Overview (d) } \\
\text { Further } \\
\text { declarations } \\
\text { proved false; } \\
\text { weapons } \\
\text { production } \\
\text { equipment } \\
\text { discovered }\end{array}$ & $\begin{array}{l}\text { In June 1996, a further full and final declaration was } \\
\text { made. That too turned out to be false. In June 1997, } \\
\text { inspectors were barred from specific sites. } \\
\text { In September 1997, another full and final declaration was } \\
\text { made. Also false. Meanwhile the inspectors discovered } \\
\text { VX nerve agent production equipment, something always } \\
\text { denied by the Iraqis. }\end{array}$ & $\begin{array}{l}\text { Vilification of the "Other" } \\
\text { Intent: Allude to the longstanding } \\
\text { duplicity of the Iraq regime }\end{array}$ & Not Propaganda \\
\hline 10 & $\begin{array}{l}\text { Historical } \\
\text { Overview (f) } \\
\text { 1998-now } \\
\text { Operation Desert } \\
\text { Fox as way to } \\
\text { destroy Iraqi } \\
\text { WMD capabilities; } \\
\text { new inspections } \\
\text { team brought in }\end{array}$ & $\begin{array}{l}\text { In December the inspectors left. Their final report is a } \\
\text { withering indictment of Saddam's lies, deception and } \\
\text { obstruction, with large quantities of WMD remained } \\
\text { unaccounted for. } \\
\text { The US and the UK then, in December 1998, undertook } \\
\text { Desert Fox, a targeted bombing campaign to degrade as } \\
\text { much of the Iraqi WMD facilities as we could. } \\
\text { In 1999, a new inspections team, Unmovic, was set up. } \\
\text { But Saddam refused to allow them to enter Iraq. } \\
\text { So there they stayed, in limbo, until after Resolution } \\
\text { I44I, when last November they were allowed to return. }\end{array}$ & $\begin{array}{l}\text { Vilification of the "Other" } \\
\text { Intent: Provide "character reference" } \\
\text { and context for the current } \\
\text { question before Parliament }\end{array}$ & $\begin{array}{l}\text { Not Propaganda } \\
\text { NOTE: Blair is "framing" } \\
\text { the issue very fairly, I } \\
\text { would say, but he is } \\
\text { framing nonetheless }\end{array}$ \\
\hline
\end{tabular}




\section{BETWEEN RHETORIC AND PROPAGANDA}

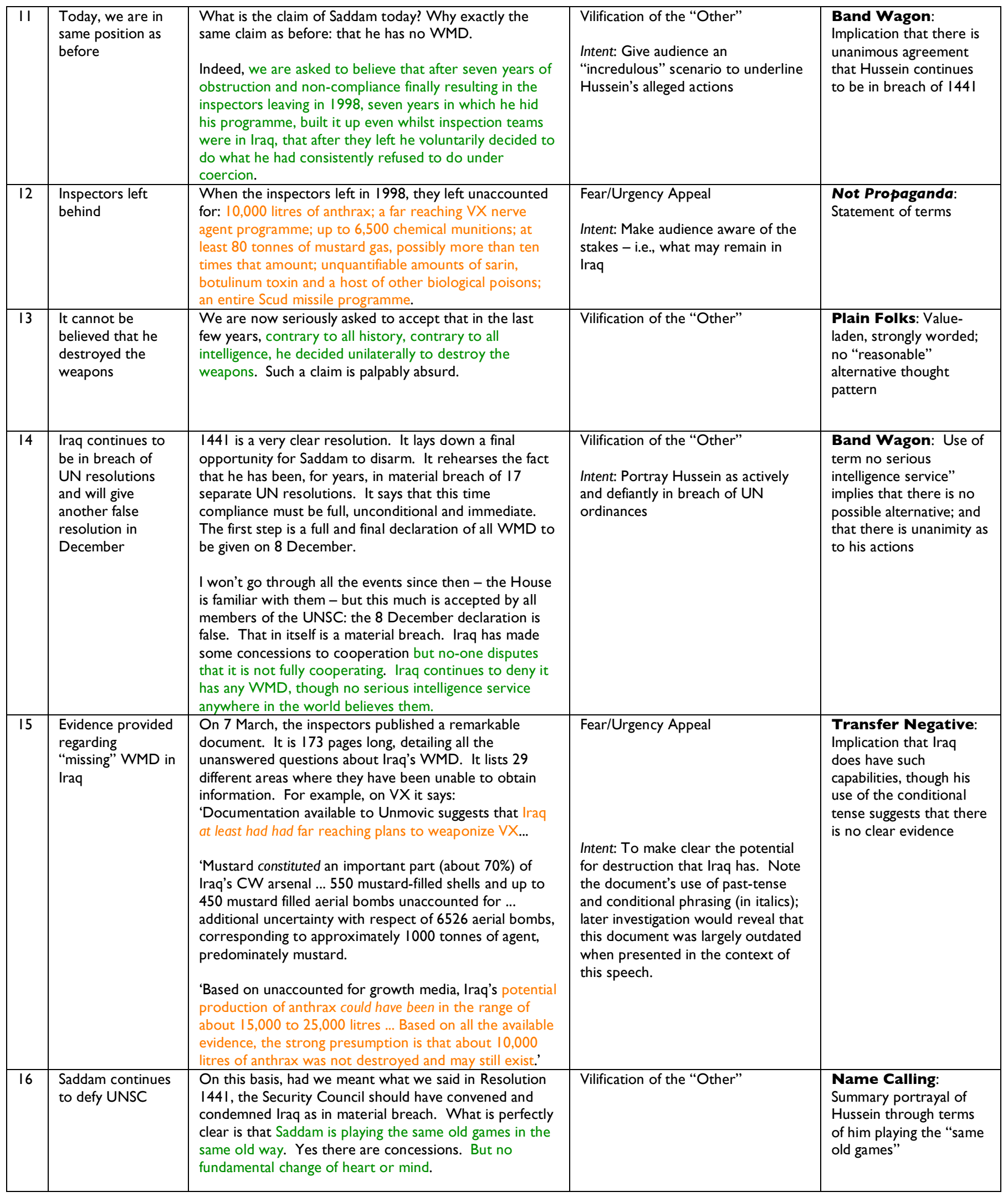




\section{BETWEEN RHETORIC AND PROPAGANDA}

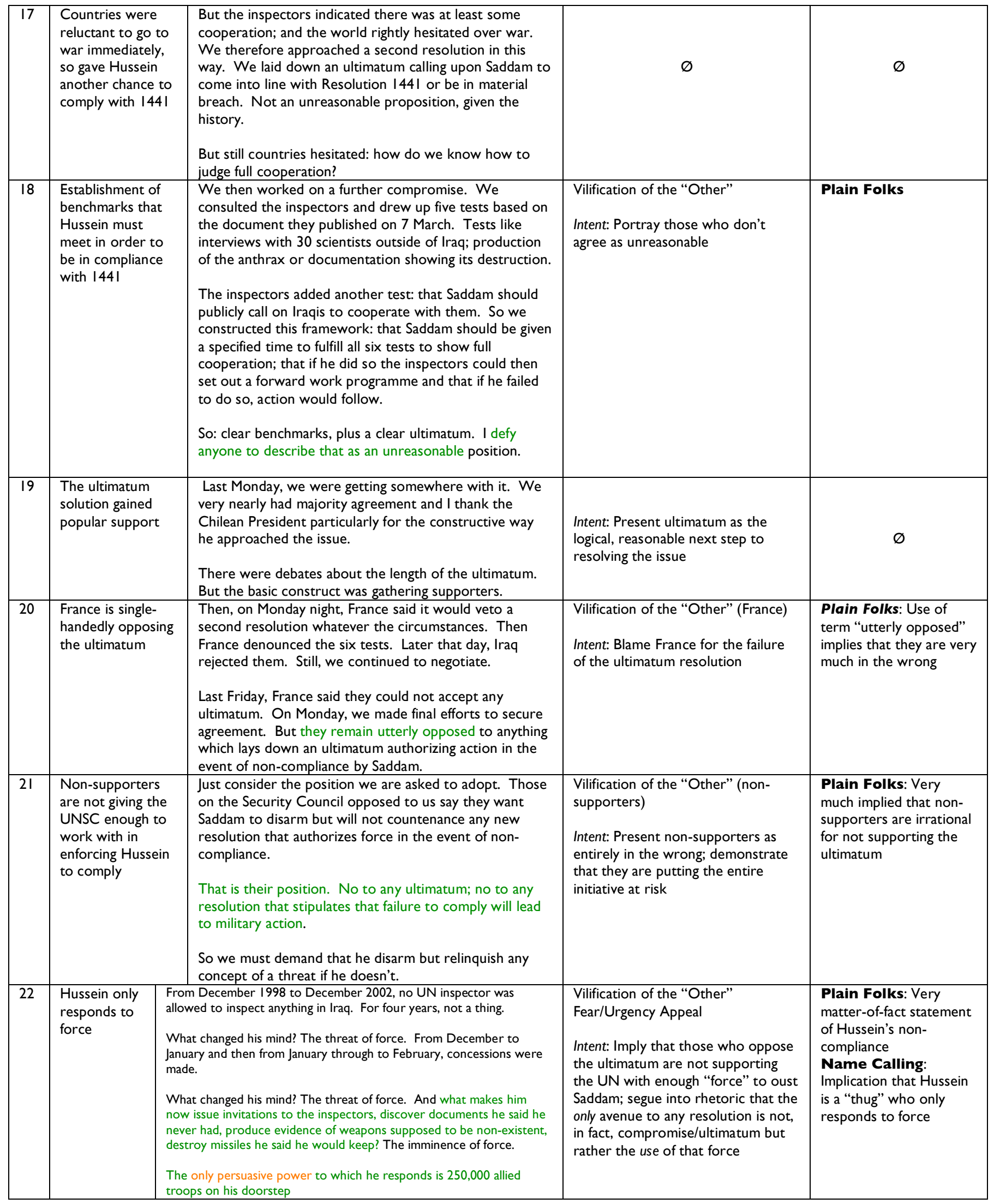




\section{BETWEEN RHETORIC AND PROPAGANDA}

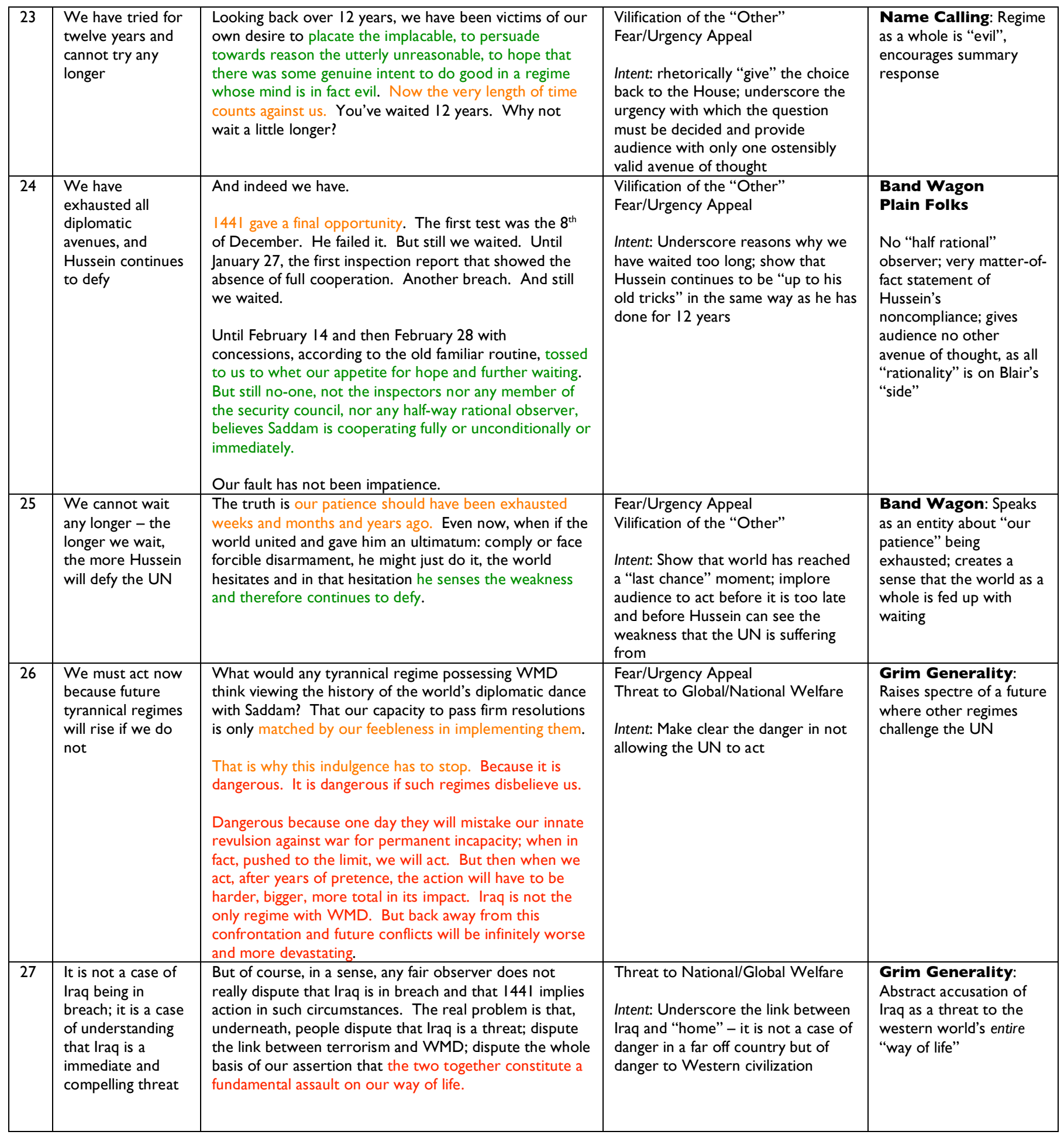




\section{BETWEEN RHETORIC AND PROPAGANDA}

\begin{tabular}{|c|c|c|c|c|}
\hline 28 & $\begin{array}{l}\text { Historical analogy } \\
\text { - while we never } \\
\text { know what to do } \\
\text { in the moment, we } \\
\text { must take past } \\
\text { instances of world } \\
\text { threats into } \\
\text { consideration } \\
\text { without dismissing } \\
\text { them as } \\
\text { "warmongering" }\end{array}$ & $\begin{array}{l}\text { There are glib and sometimes foolish comparisons with the } \\
\text { 1930s. No one here is an appeaser. But the only relevant point } \\
\text { of analogy is that with history, we know what happened. We can } \\
\text { look back and say: there's the time; that was the moment; for } \\
\text { example, when Czechoslovakia was swallowed up by the Nazis - } \\
\text { that's when we should have acted. } \\
\text { But it wasn't clear at the time. In fact at the time, many people } \\
\text { thought such a fear fanciful. Worse, put forward in bad faith by } \\
\text { warmongers. Listen to this editorial - from a paper I'm pleased } \\
\text { to say with a different position today - but written in late I938 } \\
\text { after Munich when by now, you would have thought the world } \\
\text { was tumultuous in its desire to act. } \\
\text { 'Be glad in your hearts. Give thanks to your God. People of } \\
\text { Britain, your children are safe. Your husbands and sons will not } \\
\text { march to war. Peace is a victory for all mankind. And now let us } \\
\text { go back to our own affairs. We have had enough of those } \\
\text { menaces, conjured up from the continent to confuse us.' } \\
\text { Naturally should Hitler appear again in the same form, we would } \\
\text { know what to do. But the point is that history doesn't declare } \\
\text { the future to us so plainly. Each time is different and the present } \\
\text { must be judged without the benefit of hindsight. }\end{array}$ & $\begin{array}{l}\text { Fear/Urgency Appeal } \\
\text { Historical Allusion "A" } \\
\text { Intent: Back himself out of the } \\
\text { corner of being called a } \\
\text { "warmonger"; make the comparison } \\
\text { between Hussein and Hitler; } \\
\text { underscore the need to act now, } \\
\text { rather than later. While he says he } \\
\text { isn't trying to compare to WWII, he } \\
\text { clearly is drawing a parallel with the } \\
\text { use of the editorial }\end{array}$ & $\begin{array}{l}\text { Transfer Negative: } \\
\text { Implied association } \\
\text { between Hitler and } \\
\text { Hussein, although Blair } \\
\text { expressly denies any } \\
\text { comparison with the } \\
\text { 1930s }\end{array}$ \\
\hline 31 & $\begin{array}{l}\text { Terrorists are } \\
\text { operating in } \\
\text { countries around } \\
\text { the world }\end{array}$ & $\begin{array}{l}\text { We all know that there are terrorist cells now operating in most } \\
\text { major countries. Just as in the last two years, around } 20 \text { different } \\
\text { nations have suffered serious terrorist outrages. Thousands have } \\
\text { died in them. } \\
\text { The purpose of terrorism lies not just in the violent act itself. It } \\
\text { is in producing terror. It sets out to inflame, to divide, to } \\
\text { produce consequences which they then use to justify further } \\
\text { terror. } \\
\text { Round the world it now poisons the chances of political } \\
\text { progress: in the Middle East; in Kashmir; in Chechnya; in } \\
\text { Africa. } \\
\text { The removal of the Taliban in Afghanistan dealt it a blow. } \\
\text { But it has not gone away. }\end{array}$ & $\begin{array}{l}\text { Historical Allusion "A" } \\
\text { Fear/Urgency Appeal } \\
\text { Intent: Make clear the nature and } \\
\text { goal of terrorism; increase fear of } \\
\text { terrorism by articulating that fear is } \\
\text { its very nature }\end{array}$ & $\begin{array}{l}\text { Grim Generality: } \\
\text { General point of the } \\
\text { nature of terrorism as } \\
\text { having no true purpose } \\
\text { but to increase fear }\end{array}$ \\
\hline
\end{tabular}




\begin{tabular}{|c|c|c|c|c|}
\hline 32 & $\begin{array}{l}\text { These threats } \\
\text { together will } \\
\text { assault our way of } \\
\text { life }\end{array}$ & $\begin{array}{l}\text { And these two threats have different motives and } \\
\text { different origins but they share one basic common view: } \\
\text { they detest the freedom, democracy and tolerance that } \\
\text { are the hallmarks of our way of life. } \\
\text { At the moment I accept that association between them is } \\
\text { loose. But it is hardening. }\end{array}$ & $\begin{array}{l}\text { Threat to Global/National Security } \\
\text { Vilification of the "Other" } \\
\text { Fear/Urgency Appeal } \\
\text { Intent: Show that the threat is not } \\
\text { just to people, but to fundamental } \\
\text { western way of life }\end{array}$ & $\begin{array}{l}\text { Band Wagon } \\
\text { Plain Folks } \\
\text { Show that threat is to } \\
\text { the fundamental western } \\
\text { way of life; is an } \\
\text { extension of the threat } \\
\text { from a "local" scale to } \\
\text { the grand "big picture" } \\
\text { scale }\end{array}$ \\
\hline 33 & The threat itself & $\begin{array}{l}\text { And the possibility of the two coming together - of } \\
\text { terrorist groups in possession of WMD, even of a so- } \\
\text { called dirty radiological bomb is now, in my judgment, a } \\
\text { real and present danger. }\end{array}$ & $\begin{array}{l}\text { Fear/Urgency Appeal } \\
\text { Threat to Global/National Security }\end{array}$ & $\begin{array}{l}\text { Not Propaganda: } \\
\text { Direct articulation of the } \\
\text { threat }\end{array}$ \\
\hline 35 & $\begin{array}{l}\text { This is what is still } \\
\text { unaccounted for; } \\
\text { this is what } \\
\text { terrorists are } \\
\text { capable of }\end{array}$ & $\begin{array}{l}\text { Three kilograms of } \mathrm{VX} \text { from a rocket launcher would } \\
\text { contaminate a quarter of a square kilometre of a city. } \\
\text { Millions of lethal doses are contained in one litre of } \\
\text { Anthrax. I } 0,000 \text { litres are unaccounted for. I I } \\
\text { September has changed the psychology of America. It } \\
\text { should have changed the psychology of the world. Of } \\
\text { course Iraq is not the only part of this threat. But it is } \\
\text { the test of whether we treat the threat seriously. }\end{array}$ & $\begin{array}{l}\text { Fear/Urgency } \\
\text { Threat to Global/National Welfare } \\
\text { Historical Allusion "B" }\end{array}$ & $\begin{array}{l}\text { Transfer Negative: } \\
\text { Definite emotional } \\
\text { manipulation; raises } \\
\text { speculation of what } \\
\text { terrorists are capable of, } \\
\text { directly links Iraq with } \\
\text { September II }\end{array}$ \\
\hline 37 & $\begin{array}{l}\text { If the UN does } \\
\text { not show strength } \\
\text { now, other } \\
\text { tyrannical regimes } \\
\text { will take advantage }\end{array}$ & $\begin{array}{l}\text { And then, when the threat returns from Iraq or } \\
\text { elsewhere, who will believe us? What price our } \\
\text { credibility with the next tyrant? No wonder Japan and } \\
\text { South Korea, next to North Korea, has issued such } \\
\text { strong statements of support. }\end{array}$ & $\begin{array}{l}\text { Fear/Urgency } \\
\text { Historical allusion "A" }\end{array}$ & $\begin{array}{l}\text { Grim Generality } \\
\text { NOTE: Use of rhetorical } \\
\text { questions is very } \\
\text { compelling; allows } \\
\text { audience to imagine } \\
\text { whatever "grim } \\
\text { generality" they can }\end{array}$ \\
\hline
\end{tabular}




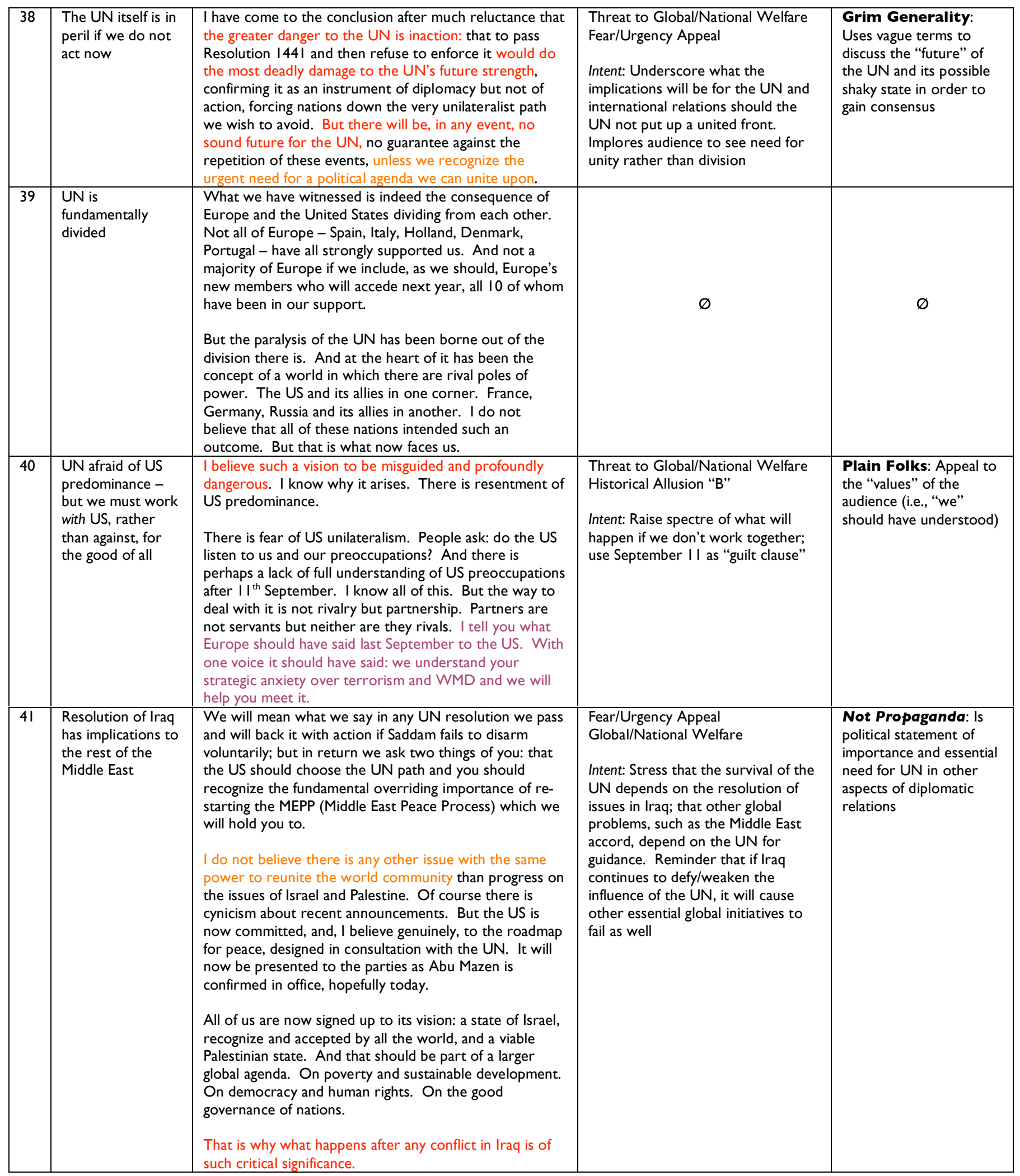




\begin{tabular}{|c|c|c|c|c|}
\hline 42 & $\begin{array}{l}\text { The future of Iraq } \\
\text { lies in uniting the } \\
\text { UN - and we } \\
\text { must provide for } \\
\text { the welfare of Iraq } \\
\text { after the } \\
\text { intervention }\end{array}$ & $\begin{array}{l}\text { Here again there is a chance to unify around the UN. } \\
\text { Let me make it clear. There should be a new UN } \\
\text { resolution following any conflict providing not just for } \\
\text { humanitarian help but also for the administration and } \\
\text { governance of Iraq. That must now be done under } \\
\text { proper UN authorization. } \\
\text { It should protect totally the territorial integrity of Iraq. } \\
\text { And let the oil revenues - which people falsely claim we } \\
\text { want to seize - be put in a trust fund for the Iraqi people } \\
\text { administered through the UN. } \\
\text { And let the future government of Iraq be given a chance } \\
\text { to begin the process of uniting the nation's disparate } \\
\text { groups, on a democratic basis, respecting human rights, } \\
\text { as indeed the fledgling democracy in Northern Iraq - } \\
\text { protected from Saddam for I } 2 \text { years by British and } \\
\text { American pilots in the no-fly zone - has done so } \\
\text { remarkably. } \\
\text { And the moment that a new government is in place - } \\
\text { willing to disarm Iraq of WMD - for which its people } \\
\text { have no need or purpose - then let sanctions be lifted in } \\
\text { their entirety. }\end{array}$ & $\begin{array}{l}\text { Fate of Iraq } \\
\text { Intent: Demonstrate/declare to } \\
\text { audience that the goal is not the } \\
\text { seizure of Iraq's national resources. } \\
\text { Underline that the UN's purpose is } \\
\text { territorial integrity and human } \\
\text { welfare }\end{array}$ & $\begin{array}{l}\text { Not Propaganda: } \\
\text { Statement of purpose }\end{array}$ \\
\hline 43 & $\begin{array}{l}\text { We aren't trying } \\
\text { to intervene in } \\
\text { Iraq's internal } \\
\text { affairs - but as we } \\
\text { will, we must do } \\
\text { so properly }\end{array}$ & $\begin{array}{l}\text { I have never put our justification for action as regime } \\
\text { change. We have to act within the terms set out in } \\
\text { Resolution I44I. That is our legal base. } \\
\text { But it is the reason, I say frankly, why if we act we should } \\
\text { do so with a clear conscience and a strong heart }\end{array}$ & $\varnothing$ & $\varnothing$ \\
\hline 44 & $\begin{array}{l}\text { Iraq's current } \\
\text { state of affairs is } \\
\text { grim - its people } \\
\text { are brutally } \\
\text { oppressed and } \\
\text { require aid }\end{array}$ & $\begin{array}{l}\text { I accept fully that those opposed to this course of action } \\
\text { share my detestation of Saddam. Who could not? Iraq is } \\
\text { a wealthy country that in 1978, the year before Saddam } \\
\text { seized power, was richer than Portugal or Malaysia. } \\
\text { Today it is impoverished, } 60 \% \text { of its population } \\
\text { dependent on food aid. Thousands of children die } \\
\text { needlessly every year from lack of food and medicine. } \\
\text { Four million people out of a population of just over } 20 \\
\text { million are in exile. The brutality of the repression - the } \\
\text { death and torture camps, the barbaric prisons for } \\
\text { political opponents, the routine beatings for anyone or } \\
\text { their families suspected of disloyalty are well } \\
\text { documented. } \\
\text { Just last week, someone slandering Saddam was tied to a } \\
\text { lamppost in a street in Baghdad, his tongue cut out, } \\
\text { mutilated and left to bleed to death, as a warning to } \\
\text { others. }\end{array}$ & $\begin{array}{l}\text { Fate of Iraqi People } \\
\text { Vilification of the "Other" } \\
\text { Intent: Provide examples of strongly } \\
\text { evocative and emotional state of } \\
\text { affairs. Underline why UN must } \\
\text { intervene }\end{array}$ & $\begin{array}{l}\text { Not Propaganda; } \\
\text { although it is heavily } \\
\text { emotional }\end{array}$ \\
\hline 45 & $\begin{array}{l}\text { We have } \\
\text { freedoms that } \\
\text { Iraqis only dream } \\
\text { of }\end{array}$ & $\begin{array}{l}\text { I recall a few weeks ago talking to an Iraqi exile and } \\
\text { saying to her that I understood how grim it must be } \\
\text { under the lash of Saddam. 'But you don't,' she replied. } \\
\text { 'You cannot. You do not know what it is like to live in } \\
\text { perpetual fear.' } \\
\text { And she is right. We take our freedom for granted. But } \\
\text { imagine not being able to speak or discuss or debate o } \\
\text { even question the society you live in. To see friends and } \\
\text { family taken away and never daring to complain. To } \\
\text { suffer the humility of failing courage in the face of pitiless } \\
\text { terror. That is how the Iraqi people live. Leave Saddam } \\
\text { in place and that is how they will continue to live. }\end{array}$ & $\begin{array}{l}\text { Vilification of the "Other" } \\
\text { Fate of Iraqi People } \\
\text { Fear and Urgency Appeal } \\
\text { Intent: Subjectively appeal to } \\
\text { audience; implore them to } \\
\text { understand need to intervene }\end{array}$ & $\begin{array}{l}\text { Not Propaganda: Is } \\
\text { extended specific } \\
\text { example of life under } \\
\text { Saddam's "lash" - poetic, } \\
\text { but legitimate }\end{array}$ \\
\hline
\end{tabular}




\section{BETWEEN RHETORIC AND PROPAGANDA}

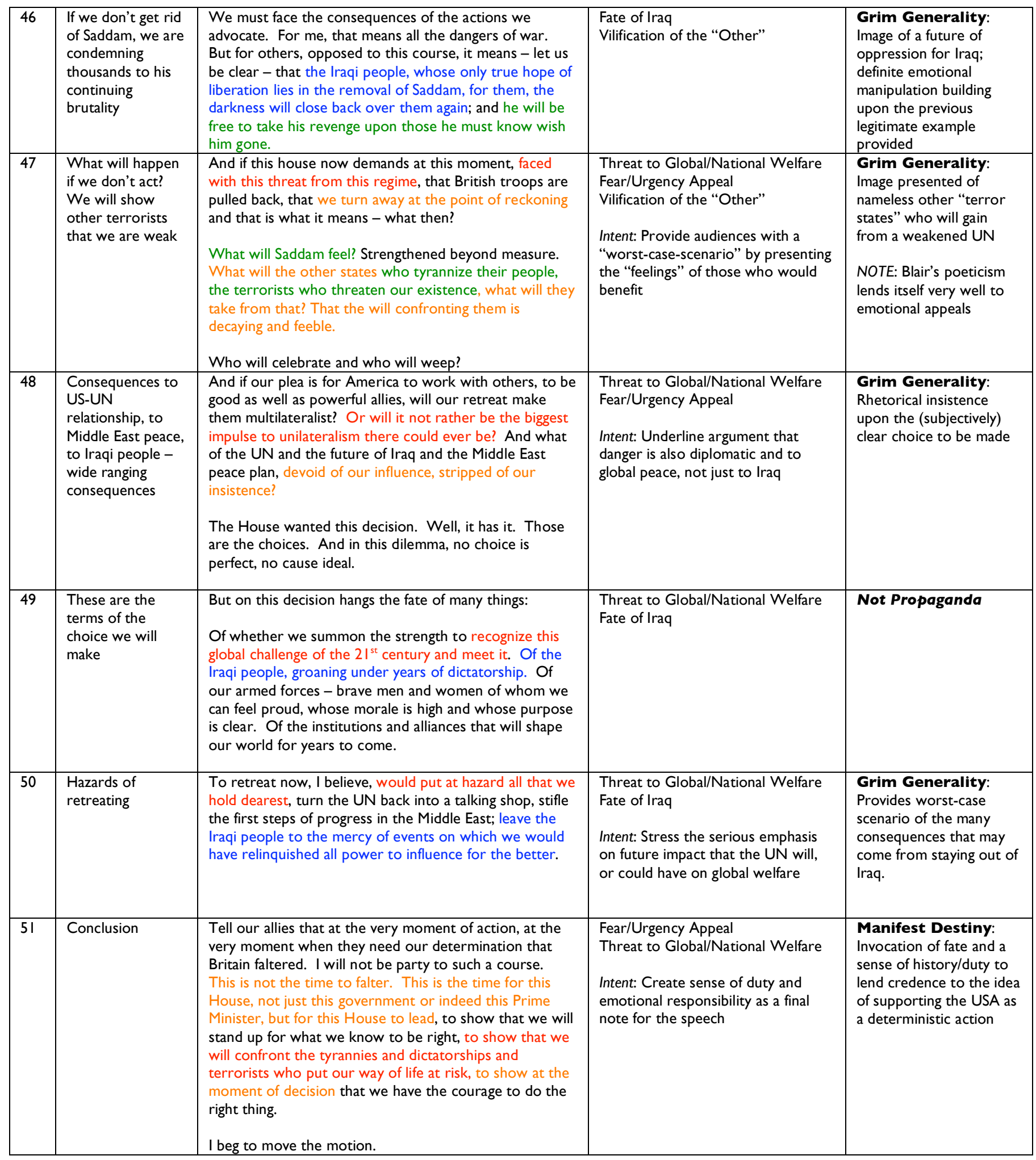




\title{
Appendix "D"
}

Article 5

Analysis: Stephen Harper's “Speech to the House of Commons"

\author{
Analysis Summary \\ Propaganda in "Speech to the House of Commons" \\ Total legitimate appeals to pathos: 6 \\ Total illegitimate appeals to pathos: 16 \\ Propaganda Percentage: 73\%
}

Total arguments that use appeals to pathos in Speech to the House of Commons: 22

Applied Pathos Code Legend

\begin{tabular}{|l|l|}
\hline Code Colour & Appeal Category \\
\hline Red & Threat to Global/National Welfare \\
\hline Orange & Fear and Urgency Appeals \\
\hline Green & Vilification of the "Other" \\
\hline Pink & $\begin{array}{l}\text { Historical Allusion “A” (prior dictatorships/international } \\
\text { struggles) }\end{array}$ \\
\hline Purple & $\begin{array}{l}\text { Historical Allusion “B” (September II attacks on Twin } \\
\text { Towers" }\end{array}$ \\
\hline Blue & Fate of Iraqi People \\
\hline
\end{tabular}




\section{Article 6 \\ Stephen Harper's "Speech to the House of Commons" Analyzed by Argument}

\begin{tabular}{|c|c|c|c|c|}
\hline & Summary & Passage & Identified Appeals to Pathos & $\begin{array}{l}\text { Propaganda Index / } \\
\text { Justification }\end{array}$ \\
\hline I & $\begin{array}{l}\text { Opening: We } \\
\text { discuss a topic of } \\
\text { extreme } \\
\text { importance }\end{array}$ & $\begin{array}{l}\text { Mr. Speaker, I stand today to speak to a matter of } \\
\text { the gravest importance that Parliament can address: } \\
\text { the matter of war and specifically the resumption } \\
\text { of war against the regime of Saddam Hussein. }\end{array}$ & $\begin{array}{l}\text { Fear/Urgency Appeal } \\
\text { Intent: Address the gravity of the } \\
\text { matter; make audience aware of the } \\
\text { importance of the issue at hand }\end{array}$ & $\begin{array}{l}\text { Manifest Destiny: } \\
\text { Deterministic/fatalistic } \\
\text { portrayal of the issues to } \\
\text { be discussed }\end{array}$ \\
\hline 2 & $\begin{array}{l}\text { Criticism of Liberal } \\
\text { government }\end{array}$ & $\begin{array}{l}\text { We appreciate that our colleagues in the Bloc } \\
\text { Quebecois have brought this motion forward } \\
\text { today. It is appropriate for two reasons. The first } \\
\text { is that it is not from the government, which has } \\
\text { consistently acted without vision and values during } \\
\text { this crisis, and even today I understand resists a } \\
\text { timely vote on these matters. }\end{array}$ & $\begin{array}{l}\text { Vilification of the "Other" (Liberal } \\
\text { Government) } \\
\text { Intent: Predispose audience to receive } \\
\text { Canadian Alliance's message more } \\
\text { favourably; criticize political opponents }\end{array}$ & $\begin{array}{l}\text { Plain Folks: Allusion to } \\
\text { the "vision and values" of } \\
\text { Canada, and } \\
\text { government's } \\
\text { abandonment of the } \\
\text { same }\end{array}$ \\
\hline 3 & $\begin{array}{l}\text { Criticism of Bloc } \\
\text { Quebecois }\end{array}$ & $\begin{array}{l}\text { It is also fitting that this historic motion, which calls } \\
\text { on us to abandon our closest friends and allies at } \\
\text { this critical time, comes from the Bloc Quebecois, } \\
\text { a party that does have values and vision but whose } \\
\text { values are different from the traditions that built } \\
\text { this country, and whose vision is a country where } \\
\text { our country as we know it would not continue to } \\
\text { exist. }\end{array}$ & $\begin{array}{l}\text { Vilification of the "Other" (Bloc } \\
\text { Quebecois) } \\
\text { Intent: Predispose audience to receive } \\
\text { Canadian Alliance's message more } \\
\text { favourably; criticize political opponents }\end{array}$ & $\begin{array}{l}\text { Plain Folks: Allusion to } \\
\text { the "vision and values" of } \\
\text { Canada, and the Bloc's } \\
\text { separation from the same } \\
\text { NOTE: By criticizing both } \\
\text { Liberal and PQ point of } \\
\text { view this early on in the } \\
\text { speech, Harper is framing } \\
\text { his point of view as the } \\
\text { "right" one }\end{array}$ \\
\hline 4 & $\begin{array}{l}\text { Historical } \\
\text { Overview }\end{array}$ & $\begin{array}{l}\text { Let us review how we came to this crossroads } \\
\text { internationally. In I99I, after the invasion of } \\
\text { Kuwait, the world judged the Iraqi regime to be a } \\
\text { dangerous aggressor. In the interests of world } \\
\text { peace and regional security, the community of } \\
\text { nations expelled Iraq from Kuwait; required Iraq to } \\
\text { surrender its dangerous arsenal, its chemical and } \\
\text { biological weapons; and to abandon its nuclear } \\
\text { weapons program. Iraq agreed to comply with } \\
\text { these demands as an enormous and victorious } \\
\text { force of allied troops and personnel, not just } \\
\text { American and British but Canadian as well, stood } \\
\text { ready to invade. }\end{array}$ & $\begin{array}{l}\text { Threat to National/Global Welfare } \\
\text { Vilification of the "Other" } \\
\text { Intent: Provide context to the issue at } \\
\text { hand }\end{array}$ & $\begin{array}{l}\text { Not Propaganda: } \\
\text { Provides historical } \\
\text { context to the issue }\end{array}$ \\
\hline 5 & $\begin{array}{l}\text { Resolution I44I } \\
\text { was unanimously } \\
\text { adopted }\end{array}$ & $\begin{array}{l}\text { We have waited I } 2 \text { years for Saddam Hussein to give } \\
\text { action to those commitments. With the threat of } \\
\text { renewed action from the US, the UK and others, on } \\
\text { November } 8,2002 \text {, the United Nations Security Council } \\
\text { passed Resolution I } 44 I \text {. It was the I } 7 \text { th Security Council } \\
\text { Resolution regarding the threat Iraq posed to international } \\
\text { peace and security. The resolution, which was adopted } \\
\text { unanimously, gave Iraq a final opportunity to demonstrate } \\
\text { immediate compliance with its disarmament obligations } \\
\text { and it promised serious consequences otherwise. } \\
\text { Over the last four months, we have seen no evidence to } \\
\text { suggest that Saddam Hussein will willingly comply with } \\
\text { Resolution I } 44 \text { I }\end{array}$ & $\varnothing$ & $\varnothing$ \\
\hline 6 & $\begin{array}{l}\text { We must stop Iraq } \\
\text { for the safety of } \\
\text { the world }\end{array}$ & $\begin{array}{l}\text { Iraq's continued defiance of the community of nations } \\
\text { presents a challenge which must be addressed. It is } \\
\text { inherently dangerous to allow a country such as Iraq to } \\
\text { retain weapons of mass destruction, particularly in light of } \\
\text { its past aggressive behaviour. If the world community fails } \\
\text { to disarm Iraq we fear that other rogue states will be } \\
\text { encouraged to believe that they too can have these most } \\
\text { deadly weapons to systematically defy international } \\
\text { resolutions and that the world will do nothing to stop } \\
\text { them. }\end{array}$ & $\begin{array}{l}\text { Vilification of the "Other" } \\
\text { Threat to Global/National Welfare } \\
\text { Fear/Urgency Appeal } \\
\text { Intent: Articulate the threat to world } \\
\text { community }\end{array}$ & $\begin{array}{l}\text { Name Calling: Points } \\
\text { to "rogue states" without } \\
\text { identifying them }\end{array}$ \\
\hline
\end{tabular}




\begin{tabular}{|c|c|c|c|c|}
\hline 7 & $\begin{array}{l}\text { If we don't address } \\
\text { Iraq, WMDs will } \\
\text { spread to terrorist } \\
\text { groups }\end{array}$ & $\begin{array}{l}\text { As the possession of weapons of mass destruction } \\
\text { spreads, the danger of such weapons coming into } \\
\text { the hands of terrorist groups will multiply, } \\
\text { particularly given in this case the shameless } \\
\text { association of Iraq with rogue non-state } \\
\text { organizations. }\end{array}$ & $\begin{array}{l}\text { Fear/Urgency Appeal } \\
\text { Vilification of the "Other" } \\
\text { Intent: Articulate threat to world } \\
\text { community }\end{array}$ & $\begin{array}{l}\text { Grim Generality: } \\
\text { Broad, general vision of } \\
\text { grim future to come } \\
\text { should Hussein remain at } \\
\text { large }\end{array}$ \\
\hline 8 & $\begin{array}{l}\text { This is the threat } \\
\text { to the world }\end{array}$ & $\begin{array}{l}\text { That is the ultimate nightmare which the world } \\
\text { must take decisive and effective steps to prevent. } \\
\text { Possession of chemical, biological or nuclear } \\
\text { weapons by terrorists would constitute a direct, } \\
\text { undeniable and lethal threat to the world, including } \\
\text { to Canada and its people. }\end{array}$ & $\begin{array}{l}\text { Fear/Urgency Appeal } \\
\text { Threat to Global/National Welfare } \\
\text { Intent: Articulate the threat in } \\
\text { definitive terms; underscore the } \\
\text { "nightmare" scenario that this would } \\
\text { entail }\end{array}$ & $\begin{array}{l}\text { Not Propaganda: Is a } \\
\text { statement of fact (i.e., it } \\
\text { would constitute a } \\
\text { threat), albeit in very } \\
\text { emotional terms }\end{array}$ \\
\hline 9 & $\begin{array}{l}\text { September II } \\
\text { allusion }\end{array}$ & $\begin{array}{l}\text { As we have learned, or should have learned, on } \\
\text { September I I, having no malice toward these } \\
\text { groups will not absolve the citizens of any country } \\
\text { from the hatred they direct toward us and toward } \\
\text { our civilization }\end{array}$ & $\begin{array}{l}\text { Historical Allusion "B" } \\
\text { Vilification of the "Other" } \\
\text { Intent: }\end{array}$ & $\begin{array}{l}\text { Transfer Negative } \\
\text { Name Calling } \\
\text { Implication that } \\
\text { September II terrorists } \\
\text { are linked with Iraq } \\
\text { regime }\end{array}$ \\
\hline 10 & $\begin{array}{l}\text { Disarmament of } \\
\text { Iraq relies on } \\
\text { removal of Hussein }\end{array}$ & $\begin{array}{l}\text { The principal objective is the disarmament of Iraq } \\
\text { but it has now become apparent that objective is } \\
\text { inseparable from the removal of Saddam Hussein's } \\
\text { regime. }\end{array}$ & $\varnothing$ & $\varnothing$ \\
\hline 11 & $\begin{array}{l}\text { Bush requested } \\
\text { support from allies }\end{array}$ & $\begin{array}{l}\text { Earlier this week President Bush requested the } \\
\text { support of his key allies in the participation of a } \\
\text { coalition of nations that would be prepared to } \\
\text { enforce Security Council resolutions by all } \\
\text { necessary means. That same day the allies } \\
\text { delivered an ultimatum to the Iraqi leadership: } \\
\text { Saddam Hussein and his sons must leave Iraq within } \\
48 \text { hours or face military conflict. }\end{array}$ & $\varnothing$ & $\varnothing$ \\
\hline 12 & $\begin{array}{l}\text { Allies tried other } \\
\text { means, but no luck }\end{array}$ & $\begin{array}{l}\text { These allies did not seek a military conflict today } \\
\text { any more than they sought it I } 2 \text { years ago. The } \\
\text { world has tried other means for years but to no } \\
\text { avail. We cannot walk away from the threat that } \\
\text { Iraq's continued possession of weapons of mass } \\
\text { destruction constitutes to its region and to the } \\
\text { wider world. }\end{array}$ & $\begin{array}{l}\text { Threat to Global/National Welfare } \\
\text { Intent: Underscore gravity of the } \\
\text { threat WMDs would pose to the } \\
\text { world at large }\end{array}$ & Not Propaganda \\
\hline 13 & $\begin{array}{l}\text { We must disarm } \\
\text { Iraq for the good of } \\
\text { the world }\end{array}$ & $\begin{array}{l}\text { In the final analysis, disarming Iraq is necessary for } \\
\text { the long-term security of the world, to the } \\
\text { collective interests of our historic allies and, } \\
\text { therefore, manifestly it is in the national interest of } \\
\text { this country. }\end{array}$ & $\begin{array}{l}\text { Fear/Urgency Appeal } \\
\text { Threat to Global/National Welfare } \\
\text { Intent: Link outcome of Iraq to national } \\
\text { welfare; is the "final analysis" (time to } \\
\text { decide) }\end{array}$ & Not Propaganda \\
\hline
\end{tabular}




\section{BETWEEN RHETORIC AND PROPAGANDA}

\begin{tabular}{|c|c|c|c|c|}
\hline 14 & $\begin{array}{l}\text { Addressing } \\
\text { Counter } \\
\text { Arguments: } \\
\text { Coalition has } \\
\text { authority to act } \\
\text { because Iraq is in } \\
\text { violation of } \\
\text { Security Council } \\
\text { resolutions }\end{array}$ & $\begin{array}{l}\text { I want to briefly address some of the counter arguments } \\
\text { to this position in support of the coalition of the willing } \\
\text { led by President Bush and Prime Minister Blair. } \\
\text { First, this coalition lacks the legal authority to act. } \\
\text { Existing United Nations Security Council resolutions } \\
\text { have long provided for the use of force to disarm Iraq } \\
\text { and restore international peace and security to the area. } \\
\text { Security Council Resolution } 678 \text { adopted in } 1990 \\
\text { authorized the use of all necessary means, not only to } \\
\text { implement Resolution } 660 \text { demanding Iraqi withdrawal } \\
\text { from Kuwait, but also to implement all subsequent } \\
\text { relevant resolutions and to restore international peace } \\
\text { and security to the area. } \\
\text { Resolution } 687 \text {, which provided the ceasefire terms for } \\
\text { Iraq in } 199 \text { I, a ceasefire not an armistice, affirmed } \\
\text { Resolution } 687 \text {. Resolution I } 1441 \text { itself confirmed that } \\
\text { Iraq had been and remains in material breach of its } \\
\text { obligations, a point on which there is unanimous } \\
\text { international agreement. }\end{array}$ & $\begin{array}{l}\text { Vilification of the "Other" } \\
\text { Intent: Demonstrate Iraq's history of } \\
\text { flouting international authority }\end{array}$ & $\begin{array}{l}\text { Not Propaganda: } \\
\text { Statement of facts }\end{array}$ \\
\hline & & $\begin{array}{l}\text { Traq's past and continuing breaches of the ceasefire } \\
\text { obligations now negate the basis for the formal ceasefire. } \\
\text { Iraq has, by its conduct, demonstrated that it did not and } \\
\text { does not accept the terms of the ceasefire. } \\
\text { Consequently, authorization for the use of force in } \\
\text { Security Council Resolution } 678 \text { has been reactivated. }\end{array}$ & & \\
\hline 15 & $\begin{array}{l}\text { Drawing parallels } \\
\text { to Operation } \\
\text { Desert Fox }\end{array}$ & $\begin{array}{l}\text { I would point out that this view of international } \\
\text { law is not new. In fact, our own Canadian } \\
\text { deployment of troops to the Gulf in } 1998 \text { in } \\
\text { Operation Desert Fox, strongly supported at the } \\
\text { time by the current Prime Minister, was } \\
\text { undertaken on the same legal basis. The Clinton } \\
\text { administration clearly understood and argued, as } \\
\text { the Bush administration does now, that existing } \\
\text { Security Council resolutions clearly allow for the } \\
\text { use of military force. }\end{array}$ & $\varnothing$ & $\begin{array}{l}\varnothing \\
\text { NOTE: Is an example of } \\
\text { Transfer Positive, but } \\
\text { not of pathos }\end{array}$ \\
\hline 16 & $\begin{array}{l}\text { Inspections } \\
\text { process has failed }\end{array}$ & $\begin{array}{l}\text { Another objection is that we only need more } \\
\text { time, that the inspection process is working and } \\
\text { that diplomacy should be given another chance. } \\
\text { Let me address this. The inspections process has } \\
\text { been a failure. It has not resulted in } \\
\text { disarmament. However, more important, the } \\
\text { inspections process is not intended to force or } \\
\text { compel disarmament. It is only intended to } \\
\text { monitor compliance. }\end{array}$ & $\varnothing$ & $\begin{array}{l}\qquad \varnothing \\
\text { NOTE: Is an example of } \\
\text { Plain Folks, but not of } \\
\text { pathos }\end{array}$ \\
\hline 17 & $\begin{array}{l}\text { Hussein only } \\
\text { responds to force }\end{array}$ & $\begin{array}{l}\text { To the extent that Saddam Hussein has complied, } \\
\text { it has only been through the constant threat of } \\
\text { force. Force has been the only language that } \\
\text { Saddam Hussein's regime has ever understood. } \\
\text { Yet even the threat of force has only convinced } \\
\text { Saddam Hussein to engage reluctantly in the } \\
\text { token, piecemeal destruction of weapons, and } \\
\text { only the most reluctant revelations of the } \\
\text { existence of weapons and weapons programs. } \\
\text { Even with over } 200,000 \text { coalition troops massed } \\
\text { at his borders, he quibbles about how interviews } \\
\text { are to be conducted with his scientists and how } \\
\text { many of the reconnaissance aircraft supporting } \\
\text { the inspectors can fly at one time. He simply } \\
\text { plays a game of cat and mouse, and he will play it } \\
\text { indefinitely. After I } 2 \text { years he does not believe } \\
\text { that the international community has the will to } \\
\text { act. He clearly believes that ongoing diplomacy } \\
\text { will ultimately be hijacked by those who simply } \\
\text { want to delay and who ultimately want inaction. }\end{array}$ & $\begin{array}{l}\text { Vilification of the "Other" } \\
\text { Intent: Provide a definitive image of } \\
\text { Hussein as brutish, childish, short } \\
\text { sighted and cruel }\end{array}$ & $\begin{array}{l}\text { Name Calling: } \\
\text { Encourages summary } \\
\text { negative evaluation of } \\
\text { Hussein }\end{array}$ \\
\hline
\end{tabular}




\section{BETWEEN RHETORIC AND PROPAGANDA}

\begin{tabular}{|c|c|c|c|c|}
\hline 18 & $\begin{array}{l}\text { Delineate } \\
\text { between } \\
\text { supporters and } \\
\text { non-supporters }\end{array}$ & $\begin{array}{l}\text { In recent months this party, the Canadian Alliance, has } \\
\text { been strongly supportive of these diplomatic efforts. } \\
\text { However, it is clear now that in some cases Saddam has } \\
\text { guessed right. For example, Jacques Chirac and the } \\
\text { Gaullists of France have once again been preoccupied } \\
\text { more with agendas targeted on the Anglo-American } \\
\text { word than on the regime of Saddam Hussein. In other } \\
\text { cases, however, Saddam has clearly made an error in } \\
\text { judgment, a final misjudgment. He underestimated our } \\
\text { American and British allies and their many friends } \\
\text { around the world. }\end{array}$ & $\begin{array}{l}\text { Vilification of the "Other" } \\
\text { Intent: Portray non-supporters as } \\
\text { inadvertently playing into Saddam's } \\
\text { hands ("he guessed right"); portray } \\
\text { supporters as those standing up to } \\
\text { Hussein }\end{array}$ & $\begin{array}{l}\text { Plain Folks: } \\
\text { Subjective } \\
\text { judgment/implication of } \\
\text { irrationality or naïveté } \\
\text { on the part of those } \\
\text { who don't support US }\end{array}$ \\
\hline 19 & $\begin{array}{l}\text { US leadership of } \\
\text { the UN is } \\
\text { necessary, not } \\
\text { detrimental, to } \\
\text { the UN }\end{array}$ & $\begin{array}{l}\text { That leads to a final criticism, that the coalition is } \\
\text { somehow inadequate because it is not unanimous and } \\
\text { because it is led by the United States of America. } \\
\text { Ironically, even as our Liberal government has } \\
\text { acknowledged, America, with Britain in particular, has } \\
\text { given strong leadership to the world on the issue of } \\
\text { Iraq. What has been accomplished in recent months } \\
\text { has only been accomplished solely because of the } \\
\text { American-British coalition and their allies and their } \\
\text { determination to act. Indeed, without strong leadership } \\
\text { of leading powers, usually the USA, the failures of the } \\
\text { United Nations are too numerous and grisly to even } \\
\text { mention. }\end{array}$ & $\begin{array}{l}\text { Fear/Urgency Appeal } \\
\text { Intent: Refer to "failures" of United } \\
\text { Nations to bolster support for US } \\
\text { leadership }\end{array}$ & $\begin{array}{l}\text { Transfer Negative } \\
\text { Grim Generality } \\
\text { Implication that UN is } \\
\text { powerless without } \\
\text { United States; that past } \\
\text { failures are result of } \\
\text { inadequate (non- } \\
\text { American) leadership }\end{array}$ \\
\hline 20 & $\begin{array}{l}\text { Canadian Alliance } \\
\text { supports USA, } \\
\text { because if we do } \\
\text { not, Canada's } \\
\text { wellbeing will be } \\
\text { compromised in } \\
\text { the future }\end{array}$ & $\begin{array}{l}\text { We in the Canadian Alliance support the American } \\
\text { position today on this issue because we share its } \\
\text { concerns and its worries about the future of the world } \\
\text { if Iraq is left unattended. Alliances are a two-way } \\
\text { process. When we are in agreement we should not } \\
\text { leave it to the United States to do all the heavy lifting } \\
\text { just because it is the world's only superpower. To do } \\
\text { so, I believe, will inevitably undermine one of the most } \\
\text { important relationships that we have. In an increasingly } \\
\text { globalized and borderless world, the relationship } \\
\text { between Canada and the United States is essential to } \\
\text { our prosperity, to our democracy and to our future. }\end{array}$ & $\begin{array}{l}\text { Threat to Global/National Welfare } \\
\text { Intent: Imply that "undermining" } \\
\text { Canada's relationship with the US by } \\
\text { not supporting them in Iraq is a } \\
\text { threat to the wellbeing of the } \\
\text { country as a whole }\end{array}$ & $\begin{array}{l}\text { Grim Generality: } \\
\text { Vague allusion to the } \\
\text { diplomatic } \\
\text { consequences of not } \\
\text { supporting the US }\end{array}$ \\
\hline 21 & $\begin{array}{l}\text { Coalition must act } \\
\text { now }\end{array}$ & $\begin{array}{l}\text { The coalition assembled by the United Sates and } \\
\text { the United Kingdom is now ready to act. It is } \\
\text { now acting. It will bring this long run conflict to } \\
\text { an end once and for all. It will bring to an end } \\
\text { the regime of Saddam Hussein and the } \\
\text { militarism, brutality and aggression that are the } \\
\text { foundations of his rule. }\end{array}$ & Vilification of the "Other" & $\begin{array}{l}\text { Not Propaganda: } \\
\text { Statement of fact }\end{array}$ \\
\hline 22 & $\begin{array}{l}\text { Underscore } \\
\text { brutality of } \\
\text { Hussein's regime }\end{array}$ & $\begin{array}{l}\text { Since Saddam came to power in 1979, more than one } \\
\text { million have died as a consequence. They have died } \\
\text { through killing and torture as individual opponents, real } \\
\text { and imagined. They have died from acts of civil war and } \\
\text { mass genocide in the north and south of the country. } \\
\text { They have died in invasions launched against his } \\
\text { neighbours. Now his final bloody chapter is being read. } \\
\text { As it is being written, make no mistake, this party will } \\
\text { not be with Saddam Hussein. We will not be neutral. } \\
\text { We will be with our allies and our friends, not militarily } \\
\text { but in spirit we will be with them in America and in } \\
\text { Britain for a short and successful conflict and for the } \\
\text { liberation of the people of Iraq. }\end{array}$ & $\begin{array}{l}\text { Vilification of the "Other" } \\
\text { (Hussein/non-supporters) } \\
\text { Fate of Iraq } \\
\text { Intent: Articulate the brutality of } \\
\text { Hussein's regime and its effect on } \\
\text { Iraqi people; galvanize audience to } \\
\text { recognize human reasons why } \\
\text { Hussein must be stopped by the } \\
\text { coalition (and why, by extension, } \\
\text { Canada should support it) }\end{array}$ & $\begin{array}{l}\text { Band Wagon: } \\
\text { Implication that being } \\
\text { "neutral" is being with } \\
\text { Hussein }\end{array}$ \\
\hline 23 & $\begin{array}{l}\text { Criticism of } \\
\text { government for } \\
\text { abandoning allies, } \\
\text { military personnel, } \\
\text { and Canadian } \\
\text { values }\end{array}$ & $\begin{array}{l}\text { We will not be with our government, for this } \\
\text { government, in taking the position it has taken, has } \\
\text { betrayed Canada's history and its values. Reading only } \\
\text { the polls and indulging in juvenile and insecure anti- } \\
\text { Americanism, the government has, for the first time in } \\
\text { our history, left us outside our British and American } \\
\text { allies in their time of need. However, it has done } \\
\text { worse. It has left us standing for northing, no realistic } \\
\text { alternative, no point of principle and no vision of the } \\
\text { future. It has left us standing with no one. Our } \\
\text { government is not part of the multilateral coalition in } \\
\text { support of this action and it has not been part of any } \\
\text { coalition opposing it; just alone, playing irrelevant and } \\
\text { contradictory games on both sides of the fence, to the } \\
\text { point where we go so far as to leave military personnel } \\
\text { in the region without the active and moral support of } \\
\text { the government that sent them there. }\end{array}$ & $\begin{array}{l}\text { Vilification of the "Other" (Liberal } \\
\text { Government) } \\
\text { Intent: Turn audience's sympathies } \\
\text { away from the leading (anti-war) } \\
\text { government by accusing them of } \\
\text { abandoning not only allies, but } \\
\text { Canadian values as a whole }\end{array}$ & $\begin{array}{l}\text { Plain Folks } \\
\text { Band Wagon } \\
\text { Implication that the only } \\
\text { rational route to take is the } \\
\text { pro-war stance of the } \\
\text { Alliance } \\
\text { NOTE: Rhetorical parallel } \\
\text { between Hussein "playing } \\
\text { games of cat and mouse" } \\
\text { with UN and Liberal } \\
\text { government "playing } \\
\text { contradictory games" in } \\
\text { not choosing a coalition to } \\
\text { stand with }\end{array}$ \\
\hline
\end{tabular}




\begin{tabular}{|c|c|c|c|c|}
\hline 24 & $\begin{array}{l}\text { Danger of not } \\
\text { joining the } \\
\text { "coalition of the } \\
\text { willing" }\end{array}$ & $\begin{array}{l}\text { This is not an act of independence. In fact, as we } \\
\text { find ourselves isolated from our allies, we found } \\
\text { ourselves under the government more dependent } \\
\text { on them than ever before, economically, culturally } \\
\text { and, of course, militarily. } \\
\text { My great fear: A country that does not embrace its } \\
\text { own friends and allies in a dangerous world but } \\
\text { thinks it can use them and reject them at will. Such } \\
\text { a country will in time endanger its own existence. }\end{array}$ & $\begin{array}{l}\text { Threat to Global/National Welfare } \\
\text { Fear/Urgency Appeal } \\
\text { Vilification of the "Other" (Liberal } \\
\text { government) } \\
\text { Intent: Underscore the many } \\
\text { implications of not supporting the US } \\
\text { - in terms of danger to future } \\
\text { diplomatic and military relations and in } \\
\text { terms of becoming overly reliant on } \\
\text { the government (dictatorship?) }\end{array}$ & $\begin{array}{l}\text { Grim Generality } \\
\text { Band Wagon } \\
\text { Allude to vague } \\
\text { endangerment of the } \\
\text { country should it not } \\
\text { side with USA }\end{array}$ \\
\hline 25 & $\begin{array}{l}\text { Historical Allusion } \\
\text { - Canada as } \\
\text { defined by war }\end{array}$ & $\begin{array}{l}\text { However, to have the future once again of a great } \\
\text { country, we must do more than stand with our } \\
\text { friends in the United Sates. We must rediscover } \\
\text { our own values. We must remember that this } \\
\text { country was forged in large part by war, terrible } \\
\text { war, but not because it was terrible and not } \\
\text { because it was easy, but because at the time it was } \\
\text { right. }\end{array}$ & $\begin{array}{l}\text { Historical Allusion "A" } \\
\text { Intent: Provide sense that Canada's } \\
\text { past heroism will hold the country in } \\
\text { the same sense in this conflict }\end{array}$ & $\begin{array}{l}\text { Transfer Positive: } \\
\text { Association of Canada's } \\
\text { history with current } \\
\text { conflict - equates the } \\
\text { issue with past Canadian } \\
\text { heroism in struggles }\end{array}$ \\
\hline 26 & $\begin{array}{l}\text { Canadian } \\
\text { identity/values } \\
\text { defined by war }\end{array}$ & $\begin{array}{l}\text { In the great wars of the last century, against } \\
\text { authoritarianism, against fascism, and against } \\
\text { communism, Canada did not merely stand with the } \\
\text { Americans, we, more often than not, led the way. } \\
\text { We did so for freedom, we did so for democracy, } \\
\text { we did so for the values of civilization itself, values } \\
\text { which continue to be embodied in our allies and } \\
\text { their leaders and are represented in their polar } \\
\text { offices, embodied and personified by Saddam } \\
\text { Hussein and the perpetrators of } 9 / 1 \mathrm{I} \text {. }\end{array}$ & Historical Allusion "A" & $\begin{array}{l}\text { Transfer Positive: } \\
\text { Association of Canada's } \\
\text { history with current } \\
\text { conflict - equates issue } \\
\text { with past Canadian } \\
\text { heroism in struggles }\end{array}$ \\
\hline 27 & $\begin{array}{l}\text { We know that the } \\
\text { Canadian people } \\
\text { support us, even if } \\
\text { the government } \\
\text { does not }\end{array}$ & $\begin{array}{l}\text { Therefore, we will not merely vote against this } \\
\text { motion today, we will tell the Americans and the } \\
\text { British that we are with them. } \\
\text { We will of course pray for the innocent people of } \\
\text { Iraq and hope that they may have a better future } \\
\text { than the one they have had under this tyrannical } \\
\text { regime, and we will wish that they may have a } \\
\text { future where they have the democratic freedoms } \\
\text { that we enjoy, that every man and every woman, } \\
\text { yes, even in the Islamic world, is entitled to in } \\
\text { every part of this earth. We will stand, and I } \\
\text { believe most Canadians will quietly stand with us, } \\
\text { for these higher values, which shaped our past and } \\
\text { which we will need in an uncertain future. }\end{array}$ & $\begin{array}{l}\text { Fate of Iraq } \\
\text { Vilification of the "Other" }\end{array}$ & $\begin{array}{l}\text { Manifest Destiny: } \\
\text { Deterministic declaration } \\
\text { of ideological right to } \\
\text { intervene (i.e., for } \\
\text { democracy, human rights, } \\
\text { etc.) }\end{array}$ \\
\hline 28 & Conclusion & $\begin{array}{l}\text { Mr. Speaker, in the days that follow may God guide } \\
\text { the actions of the President of the United Sates and } \\
\text { the American people; may God save the Queen, } \\
\text { her Prime Minister and all her subjects; and may } \\
\text { God continue to bless Canada. }\end{array}$ & $\varnothing$ & $\begin{array}{c}\quad \varnothing \\
\text { NOTE: Manifest Destiny; } \\
\text { but not pathos appeal as } \\
\text { defined by Pathos Code }\end{array}$ \\
\hline
\end{tabular}




\section{REFERENCES}

\section{Case Studies}

Blair, Tony. (I8 March, 2003). Speech to the House of Commons. [Transcript].

Presented in British House of Commons. Retrieved from www.parliament.uk,

Publications \& Records - Bound Volume Hansard, Column 758.

http://www.publications.parliament.uk/pa/cm200203/cmhansrd/vo0303/8/debtext 1303|8-06.htm.

Bush, George W. (17 March, 2003). Message to Saddam. [Transcript]. Retrieved from PresidentialRhetoric.com, Speeches.

http://www.presidentialrhetoric.com/speeches/03.17.03.html.

Harper, Stephen. (20 March, 2003). Speech to the House of Commons. [Transcript].

Presented in Canadian House of Commons. Retrieved from www.parl.gc.ca,

Publications - March 20, 2003. From Official Hansard Report, Vol. I38, No. 074, $2^{\text {nd }}$ Session, $37^{\text {th }}$ Parliament.

http://www.parl.gc.ca/HousePublications/Publication.aspx?Docld=77| 11 17\&Language=E\&

Mode= $|\#| n t-464588$.

\section{Works Cited}

Altheide, David \& Grimes, Jennifer. (2005). War Programming: The Propaganda Project and the Iraq War. The Sociological Quarterly, 46, 617-643.

Aristotle. Rhetoric of Aristotle: An Expanded Translation with Supplementary Examples for Students of Composition and Public Speaking. (Lane Cooper, Ed/Trans). New York: Appleton-Century-Crofts, 1932. 
Bernays, Edward. (1947). The Engineering of Consent. Communication and Social Action, $250,113-120$.

Bernays, Edward. (1928). Propaganda. New York: Ig Publishing, 2005.

Black, Jay. (200I). Semantics and Ethics of Propaganda. Journal of Mass Media Ethics, 16(2\&3), $121-137$.

Brader, Ted. (2005). Striking a Responsive Chord: How Political Ads Motivate and Persuade Voters by Appealing to Emotions. American Journal of Political Science, 49(2), 388-405.

Burke, Kenneth. (1939). The Rhetoric of Hitler's Battle. Published in The Philosophy of Literary Form. Berkeley: University of California Press, 1969.

Burke, Kenneth. (1969). A Rhetoric of Motives. Berkeley: University of California Press. Dumbrell, John. (2004). Bush's War: The Iraq Conflict and American Democracy. In Danchev, Alex \& MacMillan, John (Eds), Iraq War and Democratic Politics (33-44). Florence, KY: Routledge.

Falk, Richard. (2004). The Global Setting: US Foreign Policy and the Future of the Middle East. In Danchev, Alex \& MacMillan, John (Eds), Iraq War and Democratic Politics (19-32). Florence, KY: Routledge.

Herrick, James. (1992). Rhetoric, Ethics, and Virtue. Communication Studies, 43(3), I33149.

Hinnebusch, Raymond. (2007). The US Invasion of Iraq: Explanations and Implications. Critique: Critical Middle Eastern Studies, 16(3), 209-228.

Jowett, Garth \& O'Donnell, Victoria. Propaganda and Persuasion. Newbury Park, CA: Sage Publications, 1992. 
Kumar, Deepa. (2006). Media, War, and Propaganda: Strategies of Information Management During the 2003 Iraq War. Communication and Critical/Cultural Studies, 3(I), 48-69.

Lam, Maggie. (2007). Language and Politics: Use and Abuse of Language in Political Rhetoric. (Doctoral Dissertation). University of Hong Kong, Hong Kong.Olasky,

Maicas, Manuel Pares i. (1995). The Ethics of Political Communication. European Journal of Communication, I0(4), 475-495.

Marvin N. (1984). Retrospective: Bernays' Doctrine of Public Opinion. Public Relations Review, 10(3), 3-12.

Mellow, David. (2006). Iraq: A Morally Justified Resort to War. Journal of Applied Philosophy, 23(3), 293-310.

Miller, Richard B. (2008). Justifications of the Iraq War Examined. Ethics and International Affairs, 22(I), 43-67.

Oddo, John. (20II). War Legitimation Discourse: Representing 'Us' and 'Them' in Four US Presidential Addresses. Discourse \& Society, 22(3), 287-3I4.

Orwell, George. (1946). Politics and the English Language. Reprinted in Clark, Irene (Ed), Concepts in Composition: Theory \& Practice in the Teaching of Writing (22I23I). New Jersey: Lawrence Erlbaum Associates, Inc.

Propaganda. (n.). In Oxford English Dictionary Online. Retrieved from http://oxforddictionaries.com/definition/english/propaganda.

Ryan, Michael \& Switzer, Les. (2009). Propaganda and the Subversion of Objectivity: Media Coverage of the War on Terrorism in Iraq. Critical Studies on Terrorism, 2(I), 45-64. 
Scott, Shirley \& Ambler, Olivia. (2007). Does Legality Really Matter? Accounting for the Decline in US Foreign Policy Legitimacy Following the 2003 Invasion of Iraq. European Journal of International Relations, I3(I), 67-87.

Tilley, Elspeth. (2005). Responding to Terrorism Using Ethical Means: The Propaganda Index. Communication Research Reports, 22(I), 69-77.

Van Dijk, Teun. (2006). Discourse and Manipulation. Discourse \& Society, I7(3), 359383. 